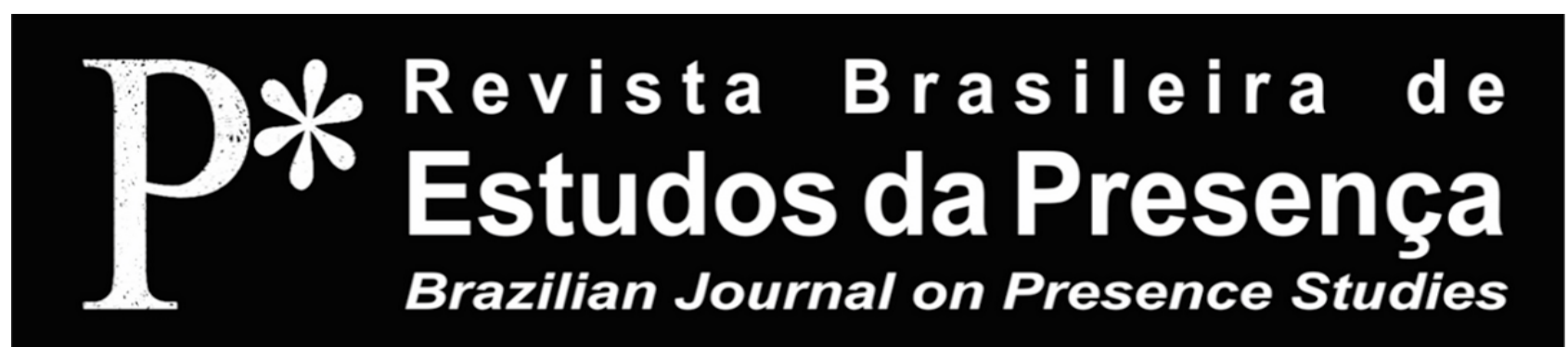

\title{
O Ballet Klauss Vianna em Belo Horizonte (1958-1962): caminhos de uma moderni- dade para o balé brasileiro
}

\author{
Arnaldo Leite de Alvarenga ${ }^{I}$ \\ IUniversidade Federal de Minas Gerais - UFMG, Belo Horizonte/MG, Brasil
}

RESUMO - O Ballet Klauss Vianna em Belo Horizonte (1958-1962): caminhos de uma modernidade para o balé brasileiro - O artigo discute quatro criaçóes coreográficas de Klauss Vianna, entre os anos de 1958 e 1962, ao elaborar uma estética própria, moderna, para o balé brasileiro. Metodologicamente sáo analisadas as imagens de quatro capas de programas do Ballet Klauss Vianna (BKV), fotografias de quatro obras que integraram esses programas, depoimentos orais, matérias e crítica jornalística da época, escritos de Vianna, autores ligados à Nouvelle Histoire, à crítica de Arte, entre outros, relacionando-os. Pretende-se destacar o potencial das imagens como ferramenta metodológica relevante para uma possível compreensão das produçóes coreográficas de Klauss Vianna na historiografia da dança no Brasil.

Palavras-chave: Imagem. Dança. Historiografia. Moderno. Artes Visuais. Klauss Vianna.

ABSTRACT - The Ballet Klauss Vianna in Belo Horizonte (1958-1962): paths of a modernity to the Brazilian ballet-The artide seeks to discuss four choreographic creations by Klauss Vianna, between the years 1958 and 1962, when elaborating his own modern aesthetic for Brazilian ballet. Methodologically, images from 4 covers of programs by Ballet Klauss Vianna (BKV), photographs from 4 works that were part of these programs, oral testimonies, articles and journalistic criticism of the time, writings by Vianna, authors linked to Nouvelle Histoire, to Art criticism, among others, relating them. It is intended to highlight the potential of images as a relevant methodological tool for a possible understanding of the choreographic productions of Klauss Vianna in the dance historiography in Brazil.

Keywords: Image. Dance. Historiography. Modern. Visual Arts. Klauss Vianna.

RÉSUMÉ - Le Ballet Klauss Vianna à Belo Horizonte (1958-1962): les chemins de la modernité pour le ballet brésilien - L'article traite de quatre créations chorégraphiques de Klauss Vianna, entre les années 1958 et 1962, lors de l'élaboration de sa propre esthétique moderne pour le ballet brésilien. Méthodologiquement, images de quatre couvertures de programmes du Ballet Klauss Vianna (BKV), photographies de quatre œuvres qui faisaient partie de ces programmes, dédarations orales, articles et critiques journalistiques de l'époque, écrits de Vianna, auteurs liés à la Nouvelle Histoire, à la critique de l'Art, entre autres, les relatant. Il vise à mettre en évidence le potentiel des images en tant qu'outil méthodologique pertinent pour une éventuelle compréhension des productions chorégraphiques de Klauss Vianna dans l'historiographie de la danse au Brésil.

Mots-dés: Image. Danse. Historiographie. Moderne. Arts Visuels. Klauss Vianna. 


\section{Consideraçóes Preliminares}

Os muitos recursos tecnológicos com os quais podemos contar nos dias atuais ampliaram, de forma considerável, as nossas possibilidades de acesso à informação. Relativamente ao aspecto centralizador do presente texto - o uso de imagens como ferramenta para se pensar uma possível historiografia -, podemos citar os filmes em películas, vídeos, fotos, pinturas, desenhos, gravuras e livros virtuais que, veiculados pela internet em plataformas e redes sociais, tornaram acessíveis muitos desses conteúdos imagéticos pela via de dispositivos como computadores e smartphones, entre outros.

Tradicionalmente, a dança é uma arte que prima por sua presencialidade materializada pelo corpo do(a) intérprete atuando frente a alguém que o(a) observa. Isto posto, vem a questão, que, desde há muitos séculos, persegue criadores e pesquisadores, que é a perenização das criaçóes de dança, sua manutenção, registro e transmissão, seja no presente ou para um futuro que se atualiza sem pausas. Tais questôes, por sua vez, nos aproximam dos esforços de muitos(as) pesquisadores(as) preocupados em pensar uma historiografia para dança que também busca a utilização desses recursos. Vejamos, entâo.

As pesquisas em História sofreram uma importante transformaçáo a partir das décadas iniciais do século XX, motivada pelo que passou a ser conhecido como Nouvelle Histoire ${ }^{1}$ (Nova História), por intermédio de parcerias interdisciplinares entre a História e as Ciências Sociais, resultando em que os pesquisadores multiplicassem os seus objetos de pesquisa e os métodos nelas envolvidos, gerando uma distinta produção historiográfica. Dentre esses novos objetos de pesquisa, a imagem, cada vez mais, passou a ser utilizada pelos historiadores como um vestígio do passado e, portanto, como fonte possível para a pesquisa histórica. Consideradas nas suas diversas categorias (imagens estáticas e em movimento), reconhece-se suas especificidades documentais para que possa ser tratada como tal, e náo como uma narrativa textual, uma vez que, por muitos anos, o valor do texto escrito foi hegemônico nas pesquisas em História, como nos aponta Knauss (2008, p. 152):

O caráter probatório da pesquisa histórica definiu a noção de documento como sinônimo de fonte histórica, demarcando assim o seu universo à

Arnaldo Leite de Alvarenga - O Ballet Klauss Vianna em Belo Horizonte (1958-1962): caminhos de uma 
hegemonia da fonte escrita e oficial. Este modelo foi validado pela concepção cientificista de documento e traduziu a afirmaçáo da objetividade do conhecimento como dado. É nesse sentido que as imagens foram desprezadas. De modo geral, a possibilidade de usá-las como provas não favoreceu a sua valorização pela historiografia que restringiu o uso das imagens às situações em que as fontes escritas não se evidenciavam suficientes, como no caso do estudo da Antiguidade.

As análises que fazemos ao estudarmos os discursos visuais das imagens podem ser reveladores dos códigos e regras produzidos no seio de uma determinada cultura. Nesse sentido, as imagens podem nos fornecer meios de acesso a alguns modos de compreensão e interpretação de como uma determinada cultura vê o mundo, por intermédio dos sujeitos nela inseridos e das teias nas quais estáo envolvidos (Barbosa; Cunha, 2006). O acesso às imagens, para além dos seus aspectos objetivos, a materialidade da fonte em si, permitenos a conexão com elementos subjetivos, simbólicos, imaginários e das mentalidades em geral. Também, enfatiza Le Goff (2003, p. 531), citando Samaran: "Há que se tomar a palavra "documento" no sentido mais amplo, documento escrito, ilustrado, transmitido pelo som, a imagem, ou de qualquer outra maneira" [grifo meu].

Por outro lado, o uso de novos gêneros de fontes documentais não abandona a necessidade da sua crítica e verificação, buscando entende-lo a partir do levantamento e avaliação das contingências de sua construçáo tornando-o um espelho do seu tempo e lugar.

A crítica contemporânea à concepção cientificista de história conduziu também à crítica da concepçáo correspondente de documento histórico, que parte da perspectiva de que os registros do passado que chegam até os dias de hoje náo são inocentes. A afirmaçáo do universo do estudo da história das representaçóes, valorizada pelos estudos da história do imaginário, da antropologia histórica e da história cultural, impôs a revisão definitiva da definição de documento e a revalorização das imagens como fontes de representaçóes sociais e culturais. É nesse sentido que a historiografia contemporânea, ao superar a noção probatória da história, promoveu um reencontro com o estudo das imagens (Knauss, 2008, p. 153). 
Nesse caminho, o trabalho de um historiador da dança pode avançar pari passu com os procedimentos da pesquisa histórica, construindo relaçôes, considerando diferentes perspectivas do olhar e cruzamento de fontes, elaborando conclusóes que podem se aproximar ou se distanciarem do de um dado sentido. Isso é o que nos coloca entendimento de Pesavento (2003, p.31) de que "O historiador é aquele que, a partir dos traços deixados pelo passado, vai em busca da descoberta do como aquilo teria acontecido, processo este que envolve urdidura, montagem, seleção, recorte, exclusão".

Porém, imagens de dança serâo sempre fragmentos do que foi posto uma vez em cena, mas, mesmo assim, podem se constituir como fontes na busca de uma atualizaçáo do passado. Esse não é um passado como ele foi realmente, mas algo que dele restou abrindo possibilidades para o seu registro e análise, buscando construir compreensôes sobre as criaçôes e seus autores, o ambiente de sua gestaçáo e suas contingências diversas como chama atenção Velasco (2006, p. 3), apontando as imagens como "[...] verdadeiras certidóes visuais do acontecido, do passado".

Como apontado acima, entre as parcerias interdisciplinares construídas pelos historiadores, a presença das Artes Visuais e da fotografia ocupam um lugar especial nesse diálogo, constituindo uma das mais potentes fontes de recursos para a investigação de imagens. Seja pelas obras de pintura, gravura, aquarelas, esculturas, desenhos, bem como os registros fotográficos, entre outras representaçóes de cenas de dança encontradas em museus, acervos, bibliotecas e galerias, elas nos permitem um contato particular com a fugacidade de uma arte capturada no instante. Com uma funçáo diferente daquela de eternizar o que por natureza é fugas, estendendo a sua aplicação, as Artes Visuais há muito contribuem para as criaçóes de dança sob a forma de cenários, figurinos, adereços, produção visual de programas e material de divulgação como demonstram os registros existentes desde as produçóes renascentistas dos balés de corte, ${ }^{2}$ as produçôes românticas e acadêmicas ${ }^{3}$ do século XIX, assim como as criaçóes neoclássicas dos Balés Russos de Serge de Diaghilev ${ }^{4}$, nas décadas iniciais do século XX, abarcando ainda as produções da dança moderna ${ }^{5}$, pós-moderna ${ }^{6}$ e contemporânea ${ }^{7}$, nos séculos XX e XXI. 
A partir de minhas pesquisas de Mestrado Dança Moderna e Educação da Sensibilidade: Belo Horizonte (1959 - 1975) e Doutorado Klauss Vianna e o Ensino de Dança: uma Experiência Educativa em Movimento (1948 - 1990), nas quais abordei, entre outros aspectos, o tema geral aqui tratado, tomo como ponto de partida a observação e análise comparativa das imagens de 4 capas de programas do Ballet Klauss Vianna (BKV), uma de autoria desconhecida e, as outras 3 criadas pelo artista plástico Augusto Degois. Utiliza-se também imagens fotográficas de 4 coreografias que integraram esses programas, destacando aspectos das mesmas, consideradas capazes de apontar aspectos dos esforços das criaçóes de Vianna na construção de uma estética própria, dita, moderna, para o balé brasileiro, na cidade de Belo Horizonte, entre os anos de 1958 e 1962. Para ampliar as análises, utilizo, ainda, depoimentos orais, matérias e crítica jornalística da época, bem como escritos de Vianna, elencando correspondências entre as imagens e as informaçôes recolhidas das demais fontes citadas, comparando-as.

A construção dessa ideia de modernidade se faz por todo um conjunto de fatores que buscam inspiração na literatura brasileira modernista, no uso de uma pesquisa sonora, nas relaçóes travadas com o conjunto de intelectuais, escritores, cineastas e artistas que integraram a chamada Geração Complemento, bem como a participação de sua esposa Angel Vianna (com formação em Artes Plásticas), e pelo uso da linguagem matricial fundamentada no balé clássico, que Vianna busca renovar, avançando na pesquisa de movimentos mais expressivos para atingir tais objetivos.

\section{As Artes Visuais Somam-se ao Balé: Augusto Degois e o BKV, diálo- gos}

Tendo iniciado seus estudos de dança com o bailarino e professor Carlos Leite (1914-1995), em Belo Horizonte, no ano de 1948, Klauss Ribeiro Vianna ${ }^{8}$ sempre se mostrou inquieto em relação aos procedimentos didáticos e movimentos aos quais se submeteu ao longo do seu aprendizado de dança, buscando modernizar a linguagem do balé, aproximando-o de referenciais mais próximos da sua experiência cotidiana e do seu próprio tempo. É assim que, em fins de 1958, cria o seu próprio grupo amador, o BKV - Ballet Klauss 
Vianna, tendo a oportunidade de aprofundar e de ver realizadas, de maneira mais eficaz, suas pesquisas, tanto técnicas como coreográficas, e de desenvolver os processos que, teoricamente, já vinha formalizando há alguns anos, de modernizar a técnica clássica como formação e sua expressão dançada. A partir do trabalho com os alunos de sua escola e com outros de níveis mais avançados, provenientes do Ballet de Minas Gerais - criado e dirigido por Carlos Leite -, Vianna compóe seu núcleo de bailarinos, e, juntamente com sua esposa e também bailarina, Angel Vianna, instauram o balé moderno em Belo Horizonte.

Entre a fundação do núcleo, em 1958, e seu término, em 1962, Vianna realiza uma série de importantes trabalhos coreográficos, nos quais pôde pôr em prática suas ideias do que expectava para um possível balé brasileiro e de inspiração moderna, cujas características inovadoras revelam-se de muitas formas, como veremos. Em função das limitaçóes dessa publicação, bem como das possibilidades de acesso, e mesmo da inexistência - até o presente momento desta pesquisa -, de outras fontes possíveis, destacarei 4, dentre as criações de Vianna inseridas nos programas analisados, nas quais considero poder reconhecer onde suas propostas de renovação melhor se evidenciam, são elas: Cobra Grande; Caso do Vestido; Arabela, a Donzela e o Mito e Marília de Dirceu,

Atento ao seu tempo, Vianna integra, em Belo Horizonte, a chamada Geração Complemento, um grupo de intelectuais, literatos, jornalistas, músicos, artistas de teatro e dança e cineastas, cujas açóes se fortaleceram na segunda metade da década de 1950, quando, em fevereiro de 1956, começa a circular a revista literária Complemento, dita a revista da nova geração, englobando várias expressóes artísticas que abrangiam, segundo o crítico de cinema Carlos Denis para o Jornal Estado de Minas (1956):

[...] poesia, canto, ensaios, notas críticas, cinema, teatro, música e artes plásticas dentro das possibilidades limitadas da revistinha [...] vale como manifestaçóes da nossa gente nova, nascendo para a vida intelectual e querendo dar vazão às suas manifestaçóes literárias e artísticas ao gosto de cada um de seus componentes $[\ldots]^{9}$. 
Nesse contexto, as Artes Visuais, em Belo Horizonte ${ }^{10}$, há muito já dialogavam com as inovaçóes presentes na chamada arte moderna, que passará a ter importante influência nos trabalhos de Vianna, principalmente pelas obras de Augusto de Gois e Wilma Martins. Augusto Degois (grafia do seu nome artístico) - pintor, desenhista, tapeceiro e cenógrafo - fruto da Escola Guignard ${ }^{11}$, foi aluno de Edith Behring ${ }^{12}$ e de Guignard ${ }^{13}$, trabalhando na criação de diversos cenários para coreografias de Vianna, prática que iniciou ao lado de João Ceschiatti ${ }^{14}$. Criou, também, ilustrações para jornais e revistas - entre elas a Complemento - o que o levou a idealizar o desenho gráfico de vários programas do BKV. Wilma Martins, também integrada aos artistas da Geraçâo Complemento, destacou-se no campo da ilustração para jornais e revistas, bem como na criação de figurinos para os balés de Klauss (Ávila, 1997).

Por intermédio das criaçóes de Augusto Degois para os programas de espetáculos do BKV, pode-se constatar a busca de elementos estéticos partilhados, que nortearam as pesquisas de Vianna, assimilando outras linguagens que pudessem contribuir não somente para uma atualizaçáo do balé, mas também para que esta atualização pudesse refletir de algum modo, um balé moderno brasileiro. Segundo, Alvarenga (2002), Klauss procurava sempre trabalhar de forma integrada com o corpo técnico de seus espetáculos, favorecendo a similaridade dos resultados de toda a criação em profícua troca de ideias. Angel Vianna ${ }^{15}$ diz: "Degois [...] vivia no nosso grupo [...] ele entendia muito [...] não só a criação do cenário, mas a integração do cenário com o próprio trabalho coreográfico, e deste com a pesquisa de música”.

Nesse caminho, a modernidade de Vianna o fará aproximar-se do ideário Modernista da Semana de $22^{16}$, que, mesmo lançando mão de influências estrangeiras, busca sua ressignificação junto aos elementos tomados à cultura nacional, valorizando nossa literatura, nossa música e as demais artes. Além de valorizar, também, elementos presentes da herança cultural popular distribuída por todo o território nacional interligando o passado com o presente, ponte necessária para modernamente transformar. 


\section{Cobra Grande: regionalismo náo é necessariamente folclore}

Entre 1959 e 1962, as criaçóes de Augusto Degois para o BKV buscam uma consonância com a modernidade pretendida por Vianna, em vivo contraste com o exemplar do programa da primeira apresentaçáo do BKV - ainda sem as contribuiçóes de Degois -, datado de 1958. No citado exemplar (Figura 1) - cuja concepção como trabalho de criação não pôde ser verificada , nota-se, ainda, a ligação do coreógrafo com um outro universo estético, esse mais próximo da sua formaçáo inicial, ou seja, o balé, vivenciado com seu professor Carlos Leite. Na capa do programa, uma diagramação simples e sóbria, executada sobre uma superfície lisa e de tons rosáceos, resume uma moldura composta de três linhas bem finas e justapostas na cor preta. Os dois conjuntos de linhas no sentido vertical, que delineiam o maior comprimento da imagem, cruzam próximo às suas extremidades o conjunto de linhas horizontais, superpondo-se a elas. Esse retângulo vertical, cujo padrão dimensional segue os princípios da seção áurea ${ }^{17}$ de proporcionalidade, envolve o seguinte texto em letra cursiva: Apresentação do Ballett Klauss Vianna - note-se que a palavra Balletté grafada com duas letras $t$. Abaixo do texto, um pequeno traço, de duas linhas de mesma espessura que as linhas da moldura, está sotoposta a um elemento de natureza vegetal, duas hastes de folhas que aportam um ar de leveza e harmonia dando um equilíbrio clássico à composição. 


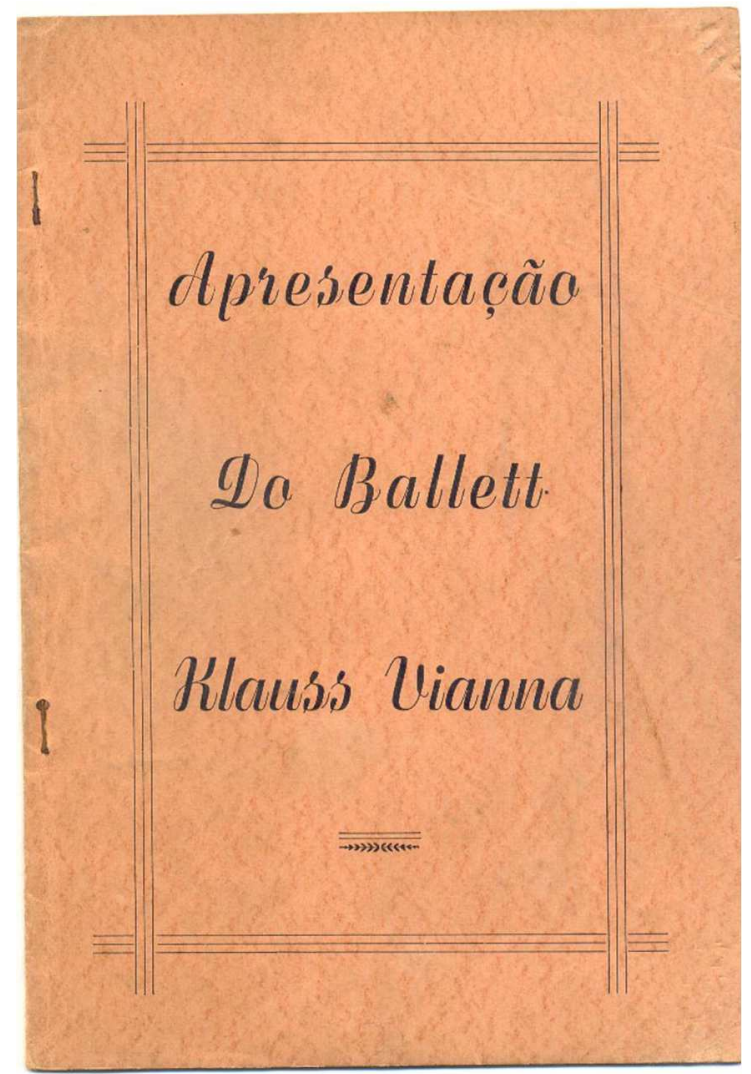

Figura 1 - Programa da primeira apresentação do Ballet Klauss Vianna (1958).

Fonte - Acervo do autor.

Embora o programa ${ }^{18}$ contivesse 4 coreografias, será destacada a remontagem de Cobra Grande (1955), criada originalmente para o Ballet de Minas Gerais, quando Vianna integrava o seu elenco - homenageando Carlos Leite -, posteriormente dançado pelo BKV e apresentado também pela televisáo carioca, TV-Rio, em uma remontagem de Vianna para o Ballet do Rio de Janeiro, em $1957^{19}$. Em entrevista ${ }^{20}$, na qual discorre sobre as bases da sua concepção coreográfica, Vianna nos informa sobre o uso do texto modernista do poeta Raul Bopp, Cobra Norato, em uma adaptação de Vera Lúcia de Lima Coelho, da música de Lorenzo Fernandez e W. Henrique e figurinos de Angel Vianna. Mesmo usando uma lenda amazônica, não é adotada uma movimentação de inspiração folclórica, que, segundo ele, demandaria outro tipo de pesquisa de fontes, extraliterárias, e de origem dos gestuais do folclore, o que se distanciava dos propósitos de seu trabalho. Preocupado com a 
autenticidade, diz que esse recurso só poderia ser bem sucedido "[...] depois de um longo e trabalhoso estudo das fontes de cada um dos temas e movimentos das danças do povo, senão vai-se, fatalmente, cair no arremedo sem significado e sem autenticidade" 21 . Ao citar, no seu ensaio Pela Criaçâo de um Ballet Brasileiro $^{22}$ (1952), iniciativas de se criarem balés com elementos nacionais, como Uirapuru de Villa-Lobos, ou mesmo a Yara, dançados por companhias estrangeiras, ele deixa claro que tal fato náo inaugurou uma tendência, sendo apenas um fato isolado, sem maiores repercussóes. Dentro desse espírito, e atuando claramente para firmar uma legitimidade das bases que definiriam, no campo da dança brasileira, o estilo, que genuinamente representaria uma dança nacional, faz críticas aos trabalhos de outros bailarinos brasileiros - com base na sua noção de movimento-idei ${ }^{23}$-, que tentaram esse caminho. Segundo Vianna, esses trabalhos se realizaram sem a necessária pesquisa, pois para que tal se dê,

[...] é preciso muito esforço, estudo e cultura, e, sobretudo honestidade nas realizaçóes. Quanto aos ballets de Eros Volúsia, Solano Trindade, a Brasiliana, etc., são pura exploração do exótico e do burlesco sem qualquer orientação mais séria, ou uma concepção da dança dentro do que chamo "movimentoidéia" ${ }^{24}$.

Para ele, toda renovação só se efetivaria, realmente, se fundamentada em uma técnica instituída, e essa seria a técnica clássica. Eros Volúsia e outros pequenos grupos de bailarinos que tentam fazer dança brasileira "[...] pecaram ao desprezar a técnica clássica" ${ }^{25}$; seus trabalhos não oferecem "[...] recursos dramáticos ou de expressão", e sua técnica mostra-se "muito pobre [...] são empregados recursos antiartísticos - e, portanto, nocivos - que impedem a esse gênero alcançar um desenvolvimento formal, refinado e artístico propriamente dito [...]"26. Segundo ele, no Brasil, se acredita que "[...] um ballet nacional é aquele que tem suas raízes nas danças, nos costumes, lendas e ambientes folclóricos" 27 . Apontando um caminho diferente em sua pesquisa coreográfica, diz tentar com seu ballet “[...] uma solução mais inteligente para o problema" 28 .

Os lundus, cateretês, frevos, maxixes, sambas, devem ser estudados em seus movimentos. Mas não explorados. Deve-se descobrir o "porquê" dos 
movimentos das danças populares, porque é aí que está a alma e o significado daquela dança. Mas enquanto não se fizer isso, enquanto não se puder ter tranquilidade e despreocupação para esse estudo enorme, deve-se evitar falsear a alma do povo ${ }^{29}$.

Em sua perspectiva de criar um balé moderno que atendesse às exigências de uma expressão nacional, e, segundo ele, representasse a “[...] índole do nosso povo e não suas exterioridades pseudo-folclóricas" 30 , não recorre ao folclore, pois falsearia a realidade. Por isso, diz,

$\mathrm{Na}$ tentativa de descobrir uma escola brasileira, sinto necessidade de temas nacionais cultos, que façam esquecer as danças folclóricas e populares que, embora valiosas, atrapalham a visão de muitos, e reduzem seu campo de experiência. Isso é, principalmente, um problema de limitação intelectual. Uso a literatura, algumas vezes, pela necessidade do tema nacional e, também, porque a matéria já vem pronta, mais fácil de sentir. O que tenho de fazer, entáo, é transmitir o que senti, usando essa pesquisa de estilo que venho fazendo ${ }^{31}$.

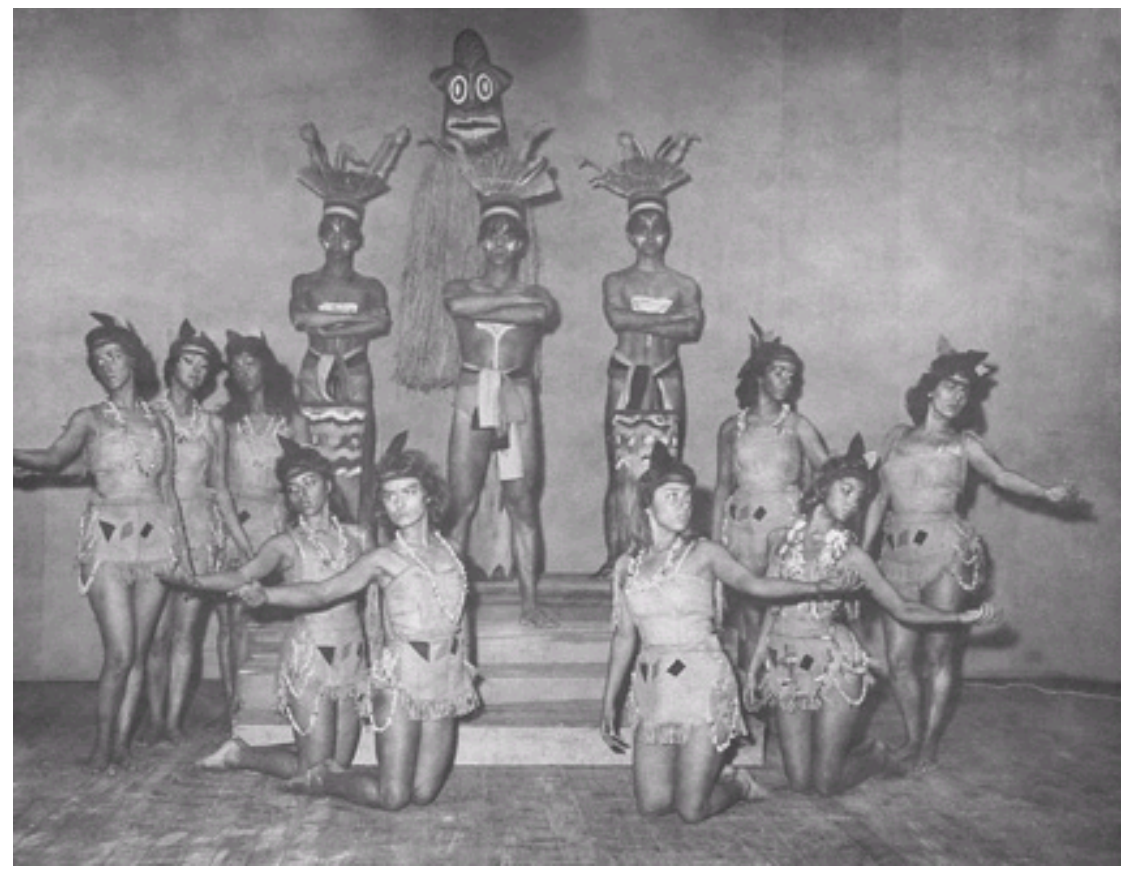

Figura 2 - Ballet Klauss Vianna, coreografia Cobra Grande, Teatro Francisco Nunes (1958).

Autor desconhecido. Fonte - Acervo do autor.

Assim, comenta Angel sobre as apresentaçóes em Belo Horizonte, na estreia do trabalho, em 1955: 
Era um balé totalmente diferente do que era feito pelo Ballet de Minas Gerais; foi a primeira coreografia de Klauss realmente bem moderna. Havia 3 Pajés, que ficavam num plano mais alto, tocando atabaques; após os Pajés entravam, em duas diagonais, as Virgens [...] para serem escolhidas pela Cobra Grande. Seus movimentos eram muito retos, e havia, por parte de Klauss, uma grande preocupaçáo quanto à qualidade do movimento que seria usado na coreografia. Seguia-se a escolha da virgem, que se dava através da luz; foi uma coisa que me surpreendeu muito, pois ele colocou um holofote que ficava andando pelo teatro todo, usando todo o espaço, com todo mundo acompanhando a luz, até que ela bate na virgem [...] Era uma coisa, assim ... mágica! [...] A cobra escolhia a virgem, a luz era a Cobra Grande! Seguia-se um ritual de preparação da virgem, [...] desciam os Pajés, que dançavam com ela, e, por fim, sendo por eles carregada, era atirada no lago ${ }^{32}$.

Chamo a atenção para o fato de que, até o momento desta escrita, não consegui outros registros fotográficos da montagem que possibilitassem maiores informaçóes sobre o desenho e expressividade dos movimentos, que na foto disponível, está mais para uma pose formal para registro. Assim, além da utilização da música, de autores brasileiros, bem como pela temática (o poema Cobra Norato), os elementos mais representativos de sua inovação estáo no uso da iluminação, descrita no depoimento de Angel, e as proposiçóes anunciadas por Vianna em sua entrevista, procurando valorizar sentidos e significados mais próximos, segundo ele, “[...] da alma do povo", a partir do seu texto de 1952, Pela Criação de um Ballet Brasileiro. Ainda segundo Angel $^{33}$, muitos bailarinos preferiram náo dançar o balé, por fugir muito daquilo que normalmente faziam. Náo eram usadas as pontas e tudo era feito com os pés descalços. $\mathrm{O}$ próprio Carlos Leite se mostrou surpreso e feliz, pois era o fruto de seu trabalho pioneiro, que, em desenvolvimento, através de seus alunos, buscava ampliação.

Ao valorizar o conteúdo na criação dos balés, Vianna procura uma maior expressividade na execução do movimento pelo bailarino, sua correta intenção ao transmitir a mensagem que pretendia com a coreografia. Ele abre máo de um movimento de efeito - seja pelo virtuosismo ou por uma busca de beleza meramente decorativa -, em favor do sentido que subjaz e que norteia a objetivação do movimento, vale dizer, prioriza a ideia que o motiva, como criação capaz de explicitar, para aquele que vê o recado que se quer dar, 
possibilitando uma fruiçáo tanto emocional quanto intelectual da obra de arte pelo espectador. Vianna, desse modo, ia impondo-se no meio cultural belo-horizontino, rompendo com duas tradiçôes: a do balé clássico nos seus moldes convencionais europeus e a utilizaçáo do folclore. Ao mesmo tempo, recorre à técnica clássica e à cultura nacional como fontes de inspiração para inaugurar uma nova tradição, ressignificando-as.

\section{Caso do Vestido: um marco da criaçáo coreográfica brasileira}

Em 1959, Augusto Degois incorpora-se à equipe técnica da nova montagem do $\mathrm{BKV}^{34}$, produzindo sua primeira capa para um trabalho de Vianna. Inspirado em poema homônimo do poeta mineiro Carlos Drummond, o balé Caso do Vestido teve, na verdade, três versóes ${ }^{35}$. No poema, uma mulher relata para as filhas como o marido a abandonou por outra mulher, cujo vestido está pendurado atrás da porta. Na primeira versão (1955), a música do maestro J. Torres acompanhava a coreografia, com cenários de Vicente de Abreu; na versão posterior (1959), os cenários são idealizados por Alfredo Muci e os figurinos por Ely-s-Ba-ot, a música por um coro que narrava o poema de Drummond, dançando-se a coreografia na dinâmica das palavras. A direçáo do coro, formado por alunos do Teatro Universitário, coube a Giustino Marzano; na versão definitiva, de 1960, os cenários foram de Augusto Degois, figurinos de Wilma Martins, e o coro, composto pelos alunos do Teatro Experimental, náo ficava mais em cena, narrando o poema de fora desta, como uma orquestra de vozes.

Pelo que podemos observar, a partir da imagem contida na Figura 3, há uma nítida diferença em relação à primeira capa analisada. Sobre um fundo todo branco, o texto grafado em preto, cujos traços sáo muito alongados no sentido vertical, desenham letras propositadamente irregulares, meio trêmulas, sugerindo quase um rabisco improvisado que anuncia, em baixo à esquerda, o objeto que justifica a criação, o ballet Klauss Vianna, estando a palavra ballet, escrita em letra minúscula. Ocupando toda a metade direita restante, três traços rápidos delineiam um corpo, formando um delgado e sugestivo croqui, no qual, braços, uma lateral de tronco e um membro inferior somam-se a uma elipse - que localiza a região da cabeça -, que se inclina 
para a esquerda, compondo um grande arco com todo o conjunto, sugerindo uma dinâmica sutil de um bailarino(a) em pose de dança. Mensagem sintética e expressiva de linhas sinuosas. Temos, aqui, uma ruptura radical com a representação figurativa do corpo em padrôes acadêmicos, ganhando, a forma em si, um valor mais absoluto. Pode-se dizer, que diante do impasse do artista moderno na valorização da forma, o expressar-se torna a criação artística muito ampla, confundindo o observador, pois, como esclarecem as palavras de Gullar (1997, p. 5), "[...] é igualmente se expressar, se se lança sobre a tela em branco um traço qualquer; se se lançam dois traços, teremos outra expressão; outra obra, se se lançam três traços, outra ainda e assim infinitamente".

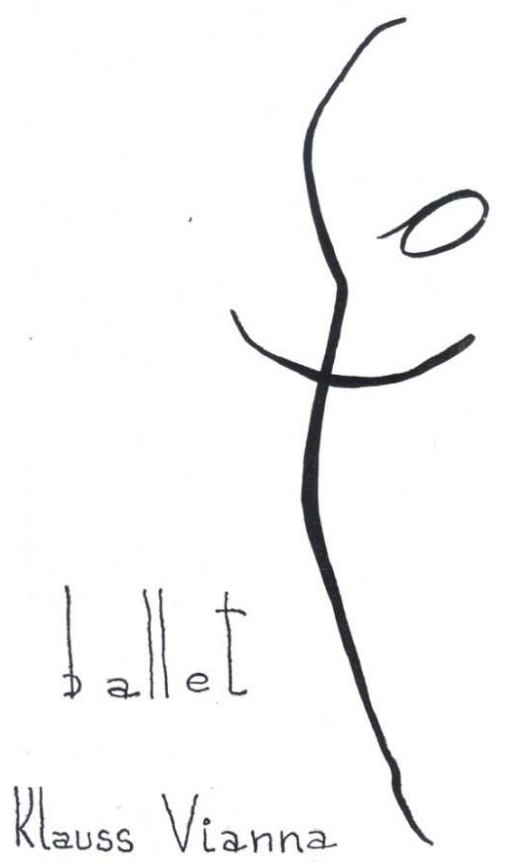

Figura 3 - Programa do Ballet Klauss Vianna (1959).

Fonte - Acervo do autor.

Com a constante possibilidade de novas leituras para o mesmo objeto artístico, presente na arte moderna, esses poucos traços, porém, não deixam de influenciar, quanto a sua proposta subjacente, o imaginário do observador, sobre o padrão físico do bailarino(a): figura delgada, alongada, sem 
adiposidades contraproducentes para a estética do ballet (diferença marcante, quando se analisa a dança moderna); não há volumes, somente linhas, que, paralelamente à palavra ballet, levam-nos a pensa-la como uma reproduçáa em letras, do corpo idealizado do intérprete. Revela-se, aí, a grande característica das linguagens artísticas modernas, que, ainda para Gullar (1997, p. 31), "[...] contêm, potencialmente, a capacidade de gerar significados novos". Chama-me a atenção que a imagem proposta se aproxima muito das figuras dos personagens da coreografia em questão, cujos figurinos são constituídos, basicamente, por uma malha justa, rente ao corpo, sem volumes, que procuram realçar as formas dos corpos que dançam e enfatizam, por sua vez, o movimento com seu valor intrínseco de poder expressivo, distintas apenas por suas cores, embora a imagem existente esteja em branco e preto (Figura 4).

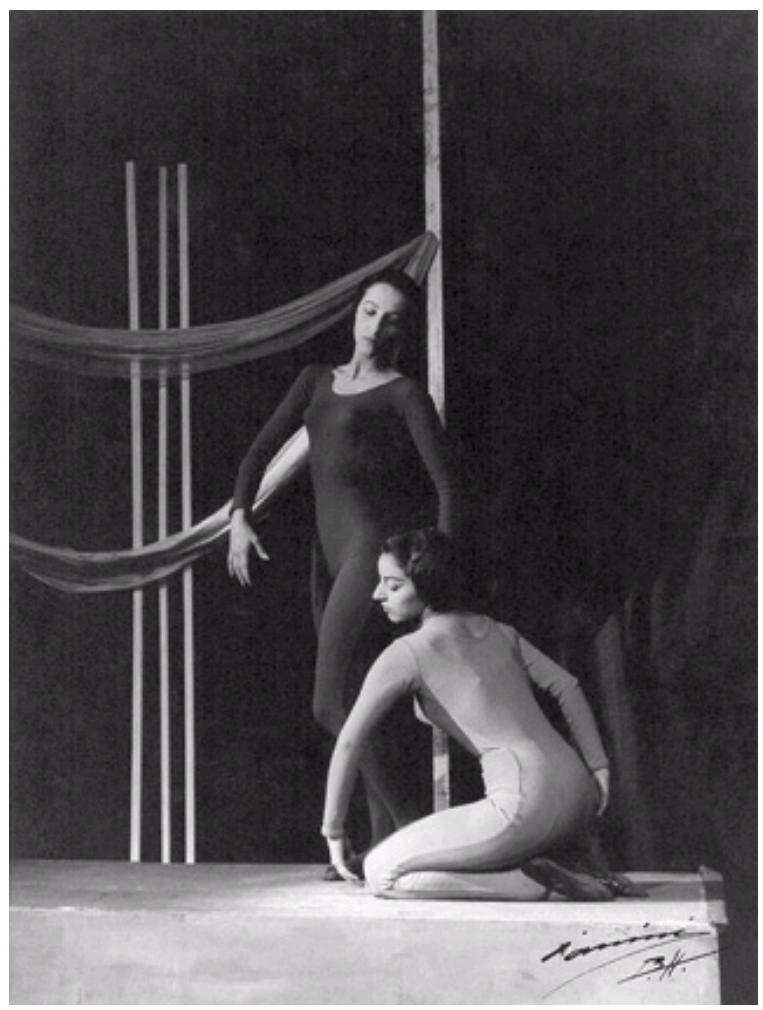

Figura 4 - Coreografia Caso do Vestido (1959), com Angel Vianna, em pé, e Marilene Martins, embaixo. Foto: Iannini. Acervo do autor. 
Segundo Vianna ${ }^{36}$, “[...] a introspecção é o sentimento chave” desse balé, contendo "[...] principalmente movimentos e linhas fechados, para dentro" $^{37}$. Angel ${ }^{38}$, que dançou o papel de uma das máes, relembra as diferenciaçóes que caracterizavam os movimentos da amante como retos e com impulsos fortes, que levassem para fora um sentimento dela; já os da mãe eram arredondados e para dentro, sugerindo aconchego.

O roteiro coreográfico de Klauss segue de perto o poema, com divisóes de planos para a compreensão do enredo. Fugindo a uma linearidade dos fatos, misturam-se passado e presente, com uma duplicação dos personagens envolvidos na história, com exceção das filhas e do pai.

Para se compreender as soluçóes que dei é preciso conhecer o poema. A história é a seguinte: a mãe explica para as filhas o caso do vestido que pertenceu a uma antiga amante de seu marido. Um dia a amante voltou já acabada, abandonada e deu à esposa aquele vestido. Eu desdobrei o poema em três planos no tempo: o primeiro plano real, o presente, com a mãe e as filhas; segundo, um plano fictício, uma espécie de volta ao passado ou "flash-back" com o marido, a amante e a mãe; terceiro, ainda em "flash-back", quando a amante, arrependida, volta e dá o vestido à mãe. Usei duas bailarinas no papel da mãe, jovem e velha, e duas no papel da amante, também jovem e velha. As passagens de um tempo para outro são feitas com a fusão e identificaçáo dos movimentos das duas bailarinas, a jovem e a velha, que ao se separarem criam dois planos diferentes, um no presente e outro no passado. Quando a amante, já acabada, volta para dar o vestido, cria-se um novo plano, pelo mesmo processo da fusáo de duas bailarinas (Machado, 2001, p. 39) (Fig. 5). 


\section{Revista Brasileira de Estudos da Presença Brazilian Journal on Presence Studies}

E-ISSN 2237-2660

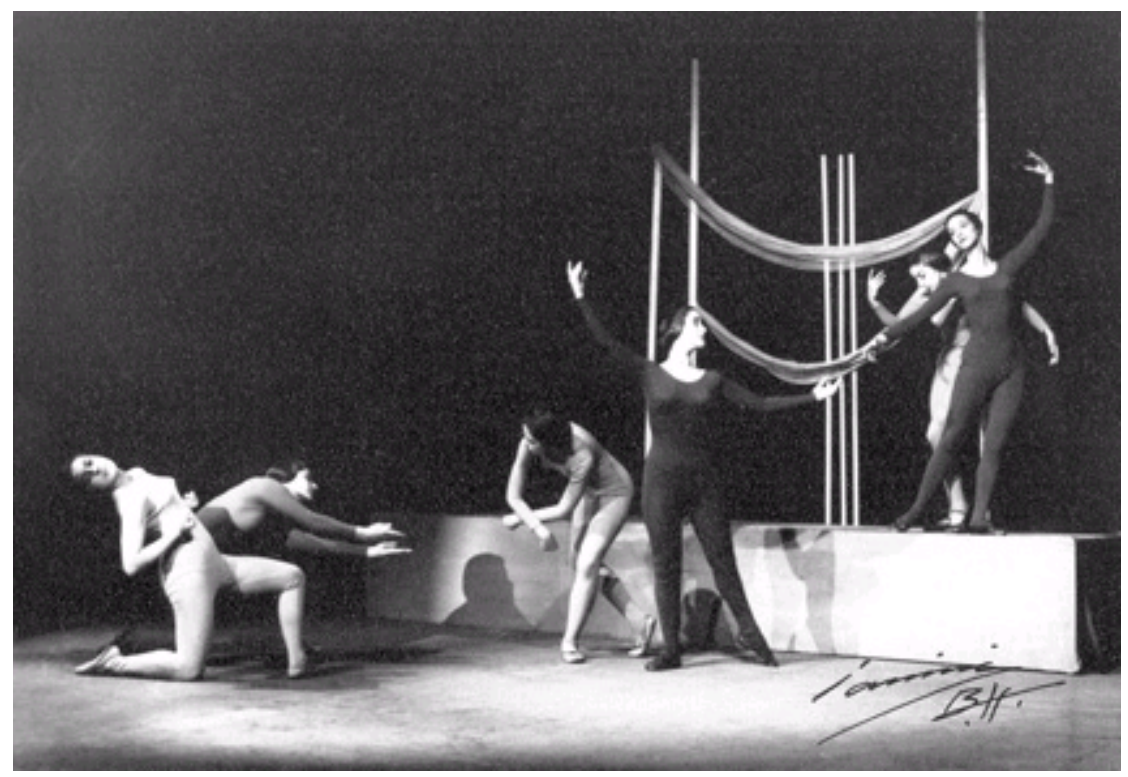

Figura 5 - Coreografia Caso do Vestido (1959), com as três duplas femininas representando os 3 diferentes planos temporais e dramatúrgicos. Fonte: Iannini. Acervo do autor.

Os recursos utilizados na coreografia destacavam-se por sua ousadia e por soluçóes incomuns na dança em Belo Horizonte, chamando a atençáo. "Klauss concebeu uma coreografia moderna, de grande força dramática", comenta Machado (2001, p. 26), entáo bailarina do grupo, e cita também a crítica do ator e diretor de teatro J. Dângelo (Machado, 2001, p. 27): "Klauss tinha os requisitos necessários e deles fez uso com admirável sensibilidade, solucionando uma questáo de tempo, com espaços, e captando as características poéticas do autor numa coreografia de admirável força dramática”. Enfatizando aspectos que a distinguiam pela sua modernidade, diz que

[...] a ausência de música era a maior inovação, mas não foi a única responsável pela importância do número. A linguagem falada casava-se perfeitamente com a linguagem corporal mostrada no palco. Os novos rumos da dança em Minas estavam definitivamente fixados ${ }^{39}$.

Ao ser levado em São Paulo, no Teatro da Cultura Artística, em 8 de novembro de 1960, um crítico ${ }^{40}$ do jornal O Estado de Sáo Paulo escrevia: "Renovação em Minas [...] esse "ballet" descritivo moderno, comprovou, desde o início, a honestidade profissional do grupo de jovens bailarinos que nos visita"; atento à qualidade dos movimentos utilizados por Vianna na 
pesquisa de cada personagem, ou seja, na busca do movimento-ideia, destaca a "[...] originalidade de tronco e braços [...] plenamente atingida", e sua distinção clara, enquanto expressão moderna, afastando-a da movimentaçáo clássica "[...] com soluções originais que fogem inteiramente ao ballet clássico, e alcançam um alto nível estético".

A bailarina Renné Gumiel, segundo depoimento de Angel ${ }^{41}$,

[...] presente na estreia [...] perguntava, surpresa, sobre onde nós [Klauss e Angel] havíamos estudado dança moderna. Ao que nós respondemos que em lugar algum, pois nunca havíamos saído do Brasil. [...] Klauss, fui criando, pois não tínhamos muito conhecimento de dança moderna; vão poucos espetáculos a Belo Horizonte e, quando muito, assistimos a algum filme no cinema [...] quando temos dinheiro, o que é raro, vamos ao Rio ver alguma companhia que lá se apresenta. Ela então disse estar encantada com a obraprima que ele havia feito e de maneira táo criativa.

Porém, na versão de 1959,

[...] alguns fatores [...] vieram prejudicar o número e tirar grande parte do impacto que ele poderia ter causado [...] a interpretaçáo do poema pelos integrantes do Teatro Universitário, sob a direçáo de Giustino Marzano, era pesada, sincopada, tirando muito da poesia do texto. [...] o coro foi colocado no palco [...] reduzindo o espaço e interferindo na plasticidade dos movimentos. Além disso, o cenário de Alfredo Muci não era adequado, e o figurino não foi feliz. As roupas eram confeccionadas com malhas pesadas e cores mal escolhidas (Machado, 2001, p. 26-27).

Atento às críticas e ao propósito final de suas pesquisas, Vianna retoma a coreografia, nela efetuando drásticas modificações: no coro, nos cenários e nos figurinos. Segundo Machado (2001), os pesados vestidos são substituídos por malhas coloridas - que já eram assumidas pela dança moderna internacional -, retirando-se os tutus e sapatos, o que rompia completamente com o esquema tradicional. Já era uma mudança - ousava algo novo e revolucionário -, mas substituir a música pelo ritmo poético das palavras era algo totalmente novo, não só, no campo belo-horizontino da dança como no cenário nacional. Era o talento criativo e investigador de Vianna que despontava.

As cores das malhas (Figura 6), criadas por Wilma Martins, caracterizavam cada personagem - o pai, a mãe, as filhas e a amante -, variando apenas 
os tons que os distinguiam no passado, mais claros, e no presente, mais escuros, sendo as cores das filhas, uma mistura das usadas para os pais.

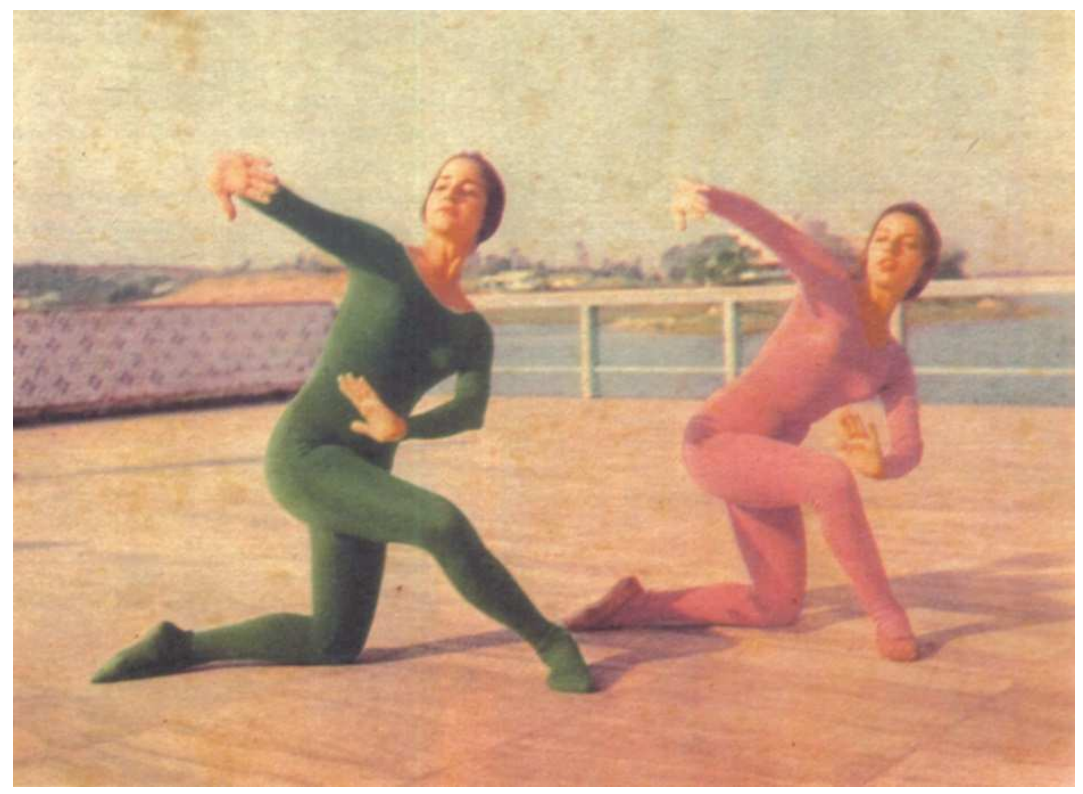

Figura 6 - Coreografia Caso do Vestido (1959), em matéria da revista O Cruzeiro, usando como fundo a região da Pampulha (Belo Horizonte). Podem-se observar as cores diferentes das malhas usadas pelas intérpretes Marilena Amorin (verde) e Marilene Martins (rosa).

Foto - Luiz Alfredo. Acervo do autor.

A cenografia, marcada pela simplicidade de uma composição abstrata, segundo Machado (2001, p. 32-33), ajudava "[...] a realçar a beleza dos movimentos", e foi dividida por Degois em dois planos: no plano baixo, a ação presente, seguindo os diálogos do texto; no plano alto, seguindo as narraçôes, o imaginário, desenrolam-se as açôes de reconstrução do passado.

O fundo sonoro, como descrito por Angel Vianna ${ }^{42}$, foi repensado por Vianna

[...] como um jogral, sobre o texto de Drummond, com o pessoal dando os ritmos diferentes conforme ele necessitava, ora mais rápidos, ora mais lentos... com repetiçóes de palavras, ele repetia! [...] Além de repetir o movimento, ele repetia a palavra para dar ênfase àquele movimento. $\mathrm{O}$ coro funcionava como uma orquestra falada, e como tudo tem vibração, um movimento vibra como vibra a voz, entáo era uma pergunta e uma resposta [...] de maneira integrada, 
a orquestra e a dança, ou seja, o coro e a dança, que tinham pergunta definida e resposta definida!

José Aurélio Vieira ${ }^{43}$, diretor do coro do Teatro Experimental,

[...] utilizando somente vozes masculinas, usou recursos técnicos para sugerir as falas femininas, usando as coloraçóes e entonaçóes correspondentes a cada personagem [...] conseguindo assim tirar dos rapazes as características próprias dos 4 temperamentos vocais, interpretados e interligados na narração e no ballet.

O crítico João Marschner, do Estado de Minas ${ }^{44}$, demonstrando a atenção da crítica no acompanhamento dos trabalhos dos artistas da capital, escreveu:

Foi com esta coreografia que Klauss no ano passado, iniciava uma pesquisa no setor da literatura como inspiração da dança. Contando desta vez com um figurinista de grande sensibilidade (Wilma Martins), Klauss depurou o trabalho, livrando-o de todos os elementos alheios à dança: são corpos envolvidos em malhas, corpos que apresentam sua silhueta nua, tal qual são nus os versos de Drummond. Pôs-se abaixo qualquer efeito espetacular [...] o coro, desta vez, era apenas um acontecimento rítmico sobre o qual se constrói a dança [...] As alunas superam com facilidade os movimentos compostos, entregando um "Caso do Vestido" em sua inteira plenitude [...] o "Caso" agora integrouse no pleno domínio de seus intérpretes[...].

Afora toda a sua relevância como obra histórica no campo da dança de Belo Horizonte e mesmo do Brasil, considero esse balé importante também sobre um outro aspecto, pois, Vianna denominava suas criaçóes como estudos, o que bem revela a trajetória do Caso do Vestido. As soluçóes imperfeitas, encontradas nas primeiras versões, vão sendo consistentemente corrigidas e levadas ao público sem medo das críticas e da exposição de uma obra ainda em construção. $\mathrm{O}$ espírito investigativo é demonstrado em seus vários caminhos de busca por uma solução mais adequada nem sempre apontada, em seus descaminhos, pelo pesquisador. Acompanhar, assim, essa conquista da solução definitiva tem, a meu ver, uma função educativa e norteadora de uma determinação e coragem necessárias em toda pesquisa realmente séria. Explicitar o erro e o percurso do coreógrafo, longe de demonstrar incapacidade do investigador, mostra os caminhos seguidos e a obstinação - virtude valiosa de 
um pesquisador - em encontrar a solução desejada. Finalmente, assim penso -, podemos relacionar a sinuosidade da figura humana, sugerida pelo risco de Degois na página branca do programa, com as figuras bem delineadas pelas malhas que revestem os corpos das intérpretes nas fotos, bem como as linhas do cenário que desenham o espaço, abstraindo da imaginação do espectador os múltiplos ambientes abrigados no poema de Drummond.

Com o Caso do Vestido, interrelacionam-se distintas linguagens artísticas, cujas contribuiçóes substanciam a plenitude de um esforço voltado para a renovação. Nesse diálogo, o núcleo central é o movimento-ideia, que se formaliza em dança. As contribuições das outras artes tornam-se mais que apoios, fundindo-se na mensagem da obra, que, sem preconceitos, sabe dialogar, amealhando diferenças numa harmônica pluralidade e aproximandonos do absoluto.

\section{Arabela, a donzela e o mito: o essencial de um romance em 15 minu- tos}

Já no ano seguinte, 1960 , a criaçáo de Degois para o programa ${ }^{45}$ do BKV (Figura 7), aproxima-se de uma linguagem que lembra a estética visual utilizada na escrita poética concretista ${ }^{46}$ - conectando-se, desse modo, com uma corrente que se afirma nesse momento do Brasil - associada ao que se pode chamar, no campo das Artes Visuais brasileiras, de Concretismo, Neoconcretismo ou Abstracionismo Geométrico ${ }^{47}$. Provavelmente, inspirando-se no grande representante dessa corrente estética, o holandês Piet Mondrian, cujo uso de cores privilegiava as cores primárias (amarelo, magenta e azul), bem como as não cores, ou seja, o branco o preto e o cinza -, Degois, em sua concepção, opta pelo uso contrastante do branco e preto, introduzindo ainda um cinza bem claro. Nesse caminho, utiliza-se de seis retângulos de diferentes dimensóes justapostos e superpostos, cuja organização, somada ao uso dos três tons, gera uma ritmicidade própria, conferindo dinamicidade à composiçáo. $\mathrm{O}$ mais verticalizado desses retângulos recebe, em seu interior, o texto com letras desalinhadas, que sugerindo movimento, parecem dançar. Por outro lado, essa disposição não convencional da escrita também força o espectador a se deslocar da sua posição passiva de observador que, formalmente, 
apenas segura um programa do espetáculo a que vai assistir, tendo, no entanto, que migrar para a condição diferenciada de alguém, que para construir a compreensão da escrita, vê-se envolvido fisicamente nesse ato, movendo as mãos, girando o programa, para conseguir lê-lo, pois que, aquilo que deve ler, está disposto perpendicularmente à linha horizontal, esperada, de uma escrita cursiva. Nesse diálogo de tons e formas geométricas afirmado no concretismo da composição analisada, Vianna reafirma o seu propósito de modernidade para o seu projeto de dança, aprofundando-se em esforços de transformação, dados a ver aqui pela visualidade parceira impressa pelas mãos e sensibilidade artística de Degois.

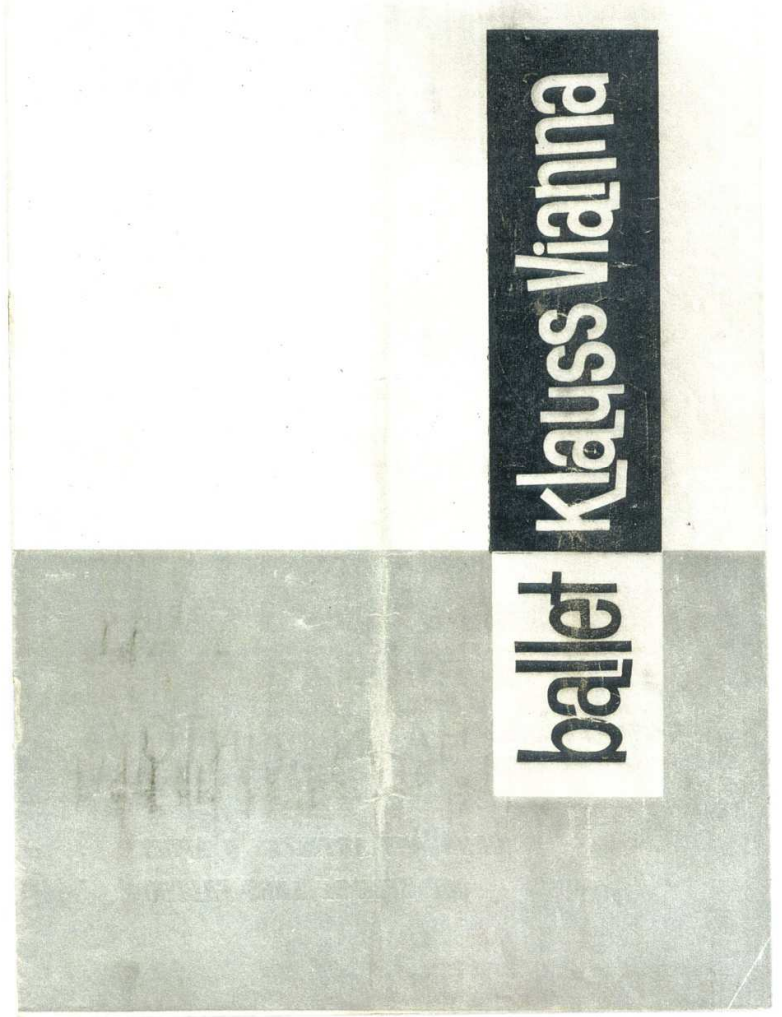

Figura 7 - Programa do Ballet Klauss Vianna (1960).

Fonte - Acervo do autor.

Arnaldo Leite de Alvarenga - O Ballet Klauss Vianna em Belo Horizonte (1958-1962): caminhos de uma 
Foi por intermédio do romance O Amanuense Belmiro (1937), de Cyro dos Anjos, que Vianna deu continuidade à utilização de obras literárias como tema de seus balés. $\mathrm{O}$ argumento é de Jacques do Prado Brandão, os figurinos de Wilma Martins e os cenários de Augusto Degois. No romance, Belmiro, um simples funcionário público, tem sua vida modificada pela procura da donzela Arabela, envolvendo-se em um processo em que se misturam a realidade e a mitificação da mulher. Na coreografia, a ousadia e a modernidade de Vianna fizeram-se notar, já, pela trilha sonora no uso de "[...] gravaçôes do barulho de uma máquina de escrever, roncos do motor de um automóvel, afinação de um violino e batidas de pandeiro [...]"48. Assim, o autor, explica a adaptação do romance:

Seria, e, é impossível tentar encaixar todo o romance de Cyro dos Anjos num ballet de 15 minutos. Tratava-se de retirar dele o essencial e fazer uma síntese do argumento. Assim, todo o aspecto da vida de funcionário de Belmiro é reduzida a dois minutos de dança, sem música, sendo o bailarino acompanhado apenas pelo barulho de uma máquina de escrever. [...] É mais uma vida seca por fora e sentida por dentro. Como o Belmiro, afinal. O principal da história, para o balé, é a procura da mulher e as confusóes com o Mito" ${ }^{49}$.

"Espetáculo corajoso, com o claro propósito de libertar o ballet brasileiro da estagnação, Klauss Vianna nele coloca, entre vários ruídos, um piano e uma bateria fazendo fundo"50 (Jornal da Cidade, 1960);

[...] no casamento de Carmela [...] o fundo sonoro é feito por barulhos ininteligíveis que sugerem farfalhar de panos, voz de padre em sermáo, pedaços de oraçóes e ladainhas [...] a cena de rua é toda feita com barulhos de motor de automóveis, arrancadas, freadas, buzinas (Noticiário Artístico, s/d).

Sem dúvida, o ponto alto da coreografia foi a sonoplastia criada por Vianna, que surpreendeu a todos pela originalidade e ousadia. Era a capital mineira integrando-se, pelo balé, em um movimento de pesquisa maior da música contemporânea internacional, que buscava, na época, novas possibilidades expressivas dos sons. Era a Música Concreta.

Sobre os outros elementos da coreografia, cenário, figurino e executantes, quando a obra, que foi apresentada no Teatro da Cultura Artística, em Sáo Paulo, assim escreve um crítico do jornal O Estado de São Paulo: 
"Arabela, a Donzela e o Mito" [...] veio novamente levantar o nível do programa. A dança vigorosa de Décimo de Castro contribuiu para o êxito dessa apresentação, além da coreografia feliz de Klauss Vianna, dos cenários de Augusto Degois e dos figurinos de muito bom gosto de Wilma Martins"51.

Seguindo em um crescendo de qualidade, revivem-se, como no Caso do Vestido, êxitos que ressaltam o investimento de Vianna no aprofundamento de recursos da linguagem cênica iniciados em seus trabalhos anteriores. A pesquisa sonora com o coro orquestral d'O Caso repete-se, agora, por intermédio da inusitada presença de sonoridades que, tal qual o movimentoideia, ampliam-se para algo - se assim posso dizer, parafraseando a noção como um som-ideia. Vale afirmar, o som fundamenta o contexto em que se insere a cena apresentada e realça o conteúdo da mensagem coreográfica pretendida. Esposa e intérprete de seus balés, Angel ${ }^{52}$ relata o processo da pesquisa sonora sobre $O$ Amanuense Belmiro:

[...] para ele, o que o funcionário público, sonoramente representava? Uma coisa de ... ritmo, é ... que pulsava igual. Toda a pulsação binária. Então, o que ele sugeriu? Como sabia que eu tocava piano, ele falou: 'vamos fazer uma experiência na máquina de escrever'. E ele falava prá mim: 'bate... tantos tempos na máquina e dando espaços, intervalos [...]. eu fui tocando na máquina, e ele foi gravando. [...] Depois, outros, é... o motor de carro. Quando liga o carro, que faz aquele barulho 'tvrummm', e que vai diminuindo quando o motor vai apagando [...] aquele sonzinho eterno... Longe, longe ... ! [...] Essa foi a grande experiência do Amanuense Belmiro".

Semelhantemente à pesquisa sonora, os movimentos coreográficos, fundamentados na busca do movimento-ideia, procuravam ressaltar também a rigidez da vida do funcionário com sua monotonia, traduzida na ritmicidade intensa da contínua repetição, como conta Angel:

[...] o movimento reto e quebrado (fig. 8). Todo movimento quebrado, encurtado. E, também, com impulsos. Repetição da máquina, repetição do motor do carro e... a repetição do movimento. [...] Não era no sentido mecânico, mas na forma da repetição [...] Exatamente o funcionário do Klauss, que ele via na época; era, coitado, um funcionário que estava ali pra sobreviver. Sobreviver e repetindo, diariamente, a mesma coisa [...] como todas as coreografias do Klauss, buscavam muito a essência do sentimento. 
[...] além dos movimentos retos, quebrados, cortados, existia uma coisa do... conter o movimento. É... o indivíduo! E o corpo de baile repetindo os movimentos. [...] O corpo de baile fazendo tudo igual [...] éramos eu, Nena, Pompéia, Dione, em uma fila, repetindo o mesmo gestual [...] $\mathrm{O}$ mesmo na dança moderna, ou contemporânea ${ }^{53}$.

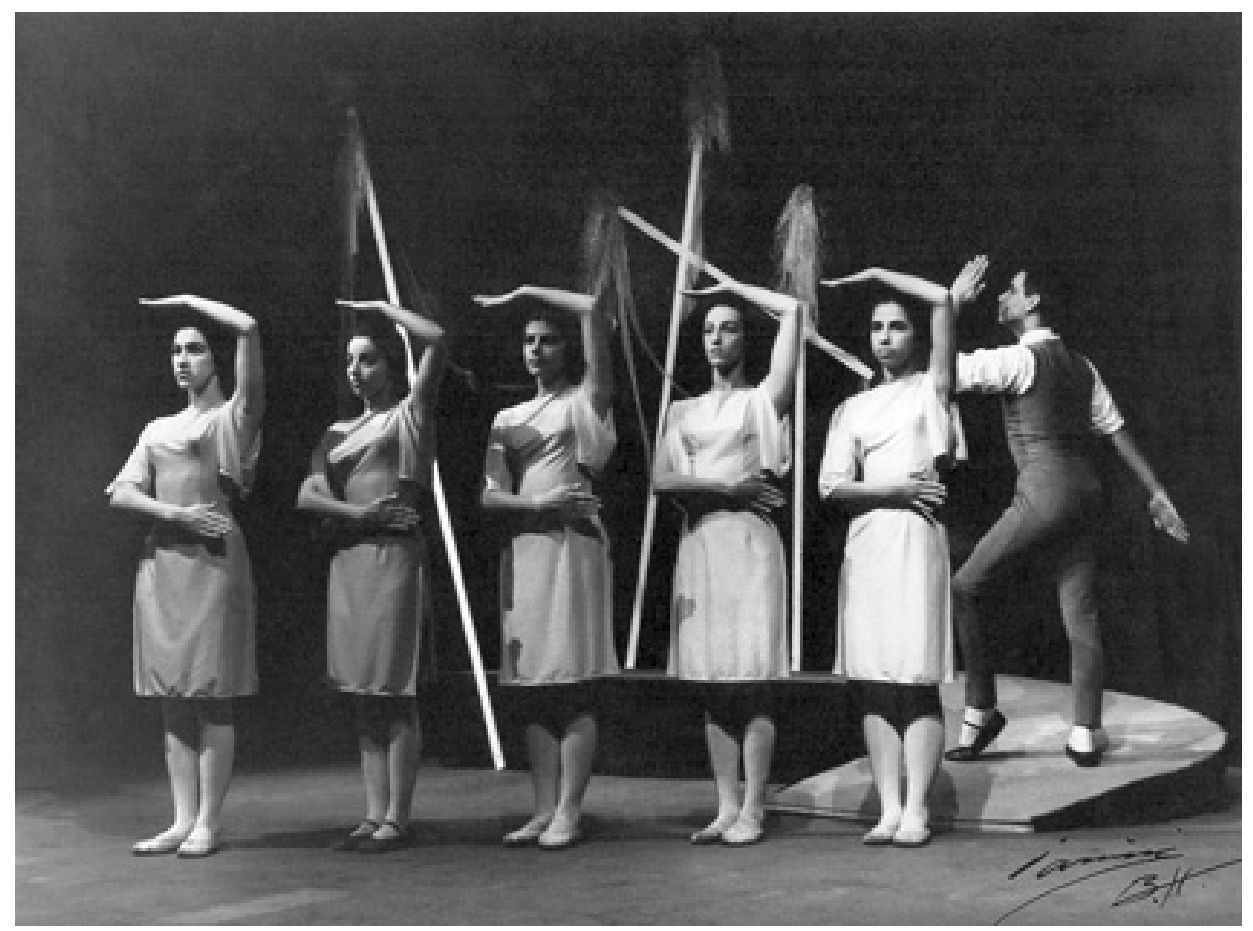

Figura 8 - Coreografia Arabela, A Donzela e o Mito (1960).

Foto: Iannini. Acervo do autor.

Ao observar, a partir da figura 8 , as posturas e o desenho corporal $\mathrm{da}(\mathrm{o}) \mathrm{s}$ intérpretes com seus movimentos quebrados e retos, retomo, pois, a imagem concretista proposta por Degois para a capa do programa, que, seguindo os mesmos traçados dos movimentos propostos por Vianna, conjuga blocos geométricos que moldam uma estrutura rígida, tal qual a coreografia estrutura blocos humanos dentro de uma rigidez cotidiana. Somam-se, a essa comparação, todos os demais elementos destacados nos dizeres da crítica e descriçôes registradas por Angel (intérprete do balé), na música da máquina de escrever, na abstração e traçado da cenografia, bem como no corte retilíneo proposto para os figurinos femininos que, ajustados ao corpo, traem na leveza das mangas que caem a suavidade da mítica donzela, Arabela em uma 
harmônica conjunção. Desse modo, penso poder dizer que, com Arabela, $A$ Donzela e o Mito, o trabalho do BKV atinge um ponto de desenvolvimento que, apesar da ainda curta existência do grupo, já demonstra a aproximação de Vianna, com sua curiosidade, sensibilidade e força investigativa de sua última obra para o BKV, como veremos a seguir.

\section{Marília de Dirceu: ponto de chegada e novo ponto de partida}

O ano de 1962 marca o derradeiro ato de existência do BKV, em função do deslocamento de Vianna e de sua família para a cidade de Salvador, onde passaria a residir e trabalhar na UFBA - Universidade Federal da Bahia - e, posteriormente, Rio de Janeiro e Sáo Paulo ${ }^{54}$. Para o programa ${ }^{55}$ dessa última apresentação, Degois utiliza o máximo de abstração (Figura 9), o que o leva a alienar-se dos objetos sensíveis, não atender a eles, por entregar-se à consideração do que se tem na imaginação. Pela abstraçáo, o entendimento forma conceitos, sendo, estes, realidades mentais - realidades abstratas -, no sentido de serem fruto do nosso entendimento. Dentro desse espírito, sobre um fundo branco, um feixe de traços riscados e fortes em preto, que têm, como núcleo, uma mancha vermelha, único ponto de cor. Mesmo sem a definiçáo de formas, os traços parecem sugerir corpos em extensão de pernas e braços que se elevam para o alto, tendo a vibraçáo intensa do desejo interno - a mancha vermelha -, o veículo motivador de um fazer que pede uma maior ampliação, uma maior expressão e expansão no mundo. $\mathrm{O}$ nome do grupo vem ocupar, de forma delicada e discreta, o pé direito da capa, em um equilibrado contraste entre abstração plena e formalismo gráfico, não sem instigar interpretaçóes possíveis, em um estilo em que a fantasia do observador é fator primordial na fruição da imagem observada, abrindo o pensamento à livre imaginação. A imagem parece querer dizer, preconizando o futuro, que ser só moderno já não bastava; tinha-se que ser vanguardista, vislumbrando e já percebendo ventos de diferentes intensidades e direçóes, acessava-se o desejo de uma contemporaneidade em gestação. 


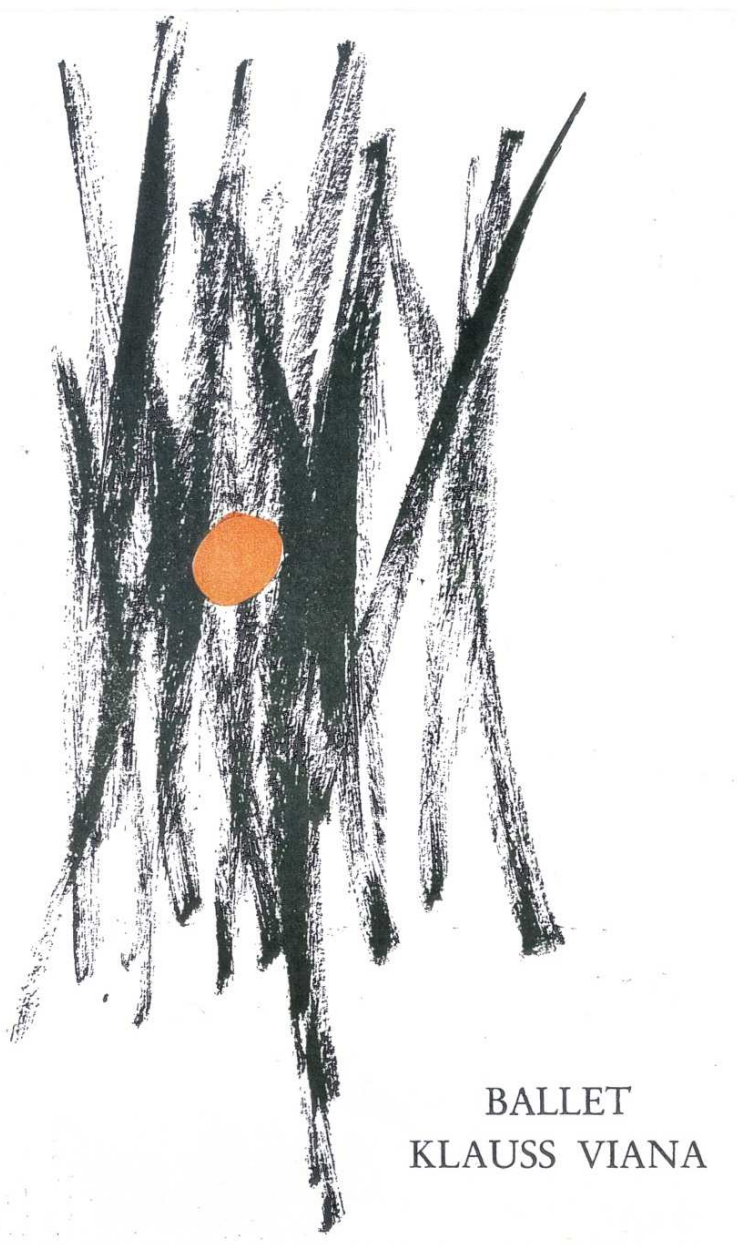

Figura 9 - Programa do Ballet Klauss Vianna (1962)

Fonte - Acervo do autor.

A pesquisa coreográfica de Vianna nos anos de 1961 e 62 produz um trabalho de grande relevância, Marília de Dirceu, última coreografia para o grupo - antes da sua dissolução -, e um ponto de sólida sustentaçáo da proposta do artista para a criação de um balé moderno e brasileiro. Dançado por Angel Vianna, Ceme Jambay e Pompéia Pires (como protagonistas), a montagem representou uma atitude contra o estilo tradicional do pas de deux. O coreógrafo procurou mostrar como a dança moderna pode apresentar soluçôes diferentes para os "[...] enfadonhos pas de deux acrobáticos do ballet clássico, ao puro jogo de virtuosismo, ao tecnicismo. Procurei mostrar, em Marília de Dirceu, um sentido de pureza e de depuração" "relativamente às 
pesquisas anteriores. Segundo Vianna, essa coreografia "[...] é o meu trabalho mais sério e mais significativo" 57 . Inspirado por sugestão de Sansão Castelo Branco, tem como pano de fundo a cidade de Ouro Preto e modinhas imperiais recolhidas por Mário Andrade, tocadas ao piano, com cenários e figurino de Degois. A estreia deu-se no I Encontro Nacional de Escolas de Dança do Brasil, realizado em Curitiba no mesmo ano. Nesse encontro, também, Vianna apresenta seu trabalho didático, renovador com o balé clássico causando grande impressão nos mestres e mestras do balé, ali presentes, tornando-se a grande revelação do evento como propositor de uma metodologia própria para algo mundialmente consagrado ${ }^{58}$.

Segundo Alvarenga (2009), na estreia do balé Marília de Dirceu, em Curitiba, a plateia ficou perplexa com a simplicidade da movimentação, basicamente uma diagonal cruzando todo o palco, na qual uma santa barroca passava como em uma procissáo do interior mineiro e em torno dela evoluíam os amantes, Marília e Dirceu, num pas de deux. Rememorando esse dia, Ricardo Teixeira de Salles, que fizera o papel masculino nessa estreia, comenta:

O cenário foi feito pelo Augusto Degois... era um oratório. Abria-se a porta e a bailarina saía, meio Nossa Senhora, assim... querendo evocar a coisa de Minas, barroca, do interior de Minas [...] O balé fugia dessa coisa do tuttu, da pontinha, do pas de bourré. Era uma concepção de movimento fora desses padrôes clássicos; "balé branco", não tinha nada de "balé branco". Inclusive muito pessoal, dele, Klauss! Era uma santa que surgia na frente de um sujeito, e esse sujeito se envolvia com ela; querendo criar... assim... uma visão do barroco mineiro ${ }^{59}$.

A bailarina e coreógrafa Lia Robatto ${ }^{60}$, também no evento, representando a Escola de Dança da UFBA, comentou sobre o misto de novidade e espanto causado pela criaçáo de Vianna, vinda de uma cidade sem nenhuma tradição de dança moderna, e cujos intérpretes trabalhavam com a técnica clássica do balé. Ela relembra:

[...] Klauss foi uma grande surpresa porque não havia comunicação fácil, não se sabia nada de Minas e, de repente, surge um professor de balé clássico, com a mulher bailarina clássica, nas pontas e tal, fazendo uma coreografia moderníssima. [...] aquilo me marcou tanto que, [...] alguns anos depois eu fiz uma coreografia e fiz uma citação desse trabalho dele [...] fiquei chocada e surpresa 
de ver como um homem, comprometido com o balé clássico, podia fazer uma coisa táo criativa, tâo nova, porque ele tinha a frescura duma novidade, da originalidade dele. Era muito linda, sem influências, estava lá, Minas, isolada de tudo. Então, não estava copiando o modelo de Nova York, porque, na época, Nova York e Argentina eram os parâmetros da dança moderna. A Europa ainda não estava entrando. [...] Mas Minas, estava isolada. [...] E esse foi o benefício dele, o fato de náo estar contaminado por influências, de ter sido uma criação! [...] Mas o Klauss tinha esse frescor da originalidade dele, e inserido na contemporaneidade da sua época. Foi lindo, em 62.

A recepção geral, porém, ocorreu entre vaias e aplausos, dando uma evidência singular à pessoa e ao trabalho de Vianna e à dança entáo produzida em Minas Gerais. Veja-se a crítica do Diário do Paraná:

Marília pegou-nos desprevenidos e somente após a sua conclusão é que o espectador pode entender que a síntese da procissáo, numa só figura, viria corresponder a outra síntese do idílio. Recapitulando, no entanto, mentalmente o espetáculo, mesmo assim há algo de irrealizado nesta síntese das duas figuras às quais a procissão se relaciona como criação de atmosfera. A esta atmosfera, todavia, não se afinava a temperatura do público, que no início era a pior possível, na expectativa do trapezista e da domadora de leóes ${ }^{61}$.

\section{Segundo Vianna,}

Entre o que lá apresentei e o que vou apresentar, hoje, há uma grande distância. Encontrei uma soluçáo bem melhor para o final, e introduzi algumas modificaçóes na coreografia que a tornaram mais definida e clara. E o bailarino que convidei para interpretar Dirceu saiu-se maravilhosamente bem ${ }^{62}$.

Tecendo críticas a um dos seus mais elogiados trabalhos, o Caso do Vestido, não vendo, nele, tudo o que idealizava para um balé genuinamente brasileiro, e como que encontrando, enfim, um sentido claro na direção que trilhava, diz:

N'o Caso do Vestido [...] havia todo um conjunto de linhas acessórias, inúteis, que impediam a plena manifestação da pureza que vejo no ballet moderno. Com "Marília de Dirceu" penso ter-me libertado de certos entraves e atingido, mediante a simplicidade dos passos, a uma certa pureza, diria, mesmo, à estrutura básica fundamental, à mais pura forma acadêmica. E é a partir dessa estrutura que pretendo trabalhar daqui para frente, no sentido de criação de um ballet brasileiro ${ }^{63}$. 
Escrevendo para o Jornal de Minas, Lúcia Machado de Almeida ${ }^{64}$, sintetiza:

Harmonia, inteligência, sensibilidade, criação, bom gosto, atualidade, tudo isso havia em cada detalhe: coreografias, guarda-roupa, cenários [...], músicas [...] Klauss não deu apenas um passo a frente, mas sim um grande e autêntico salto. Condensou-se, depurou-se e, se bem partindo de base totalmente clássica, imprimiu às suas coreografias algo de moderno, de puro e de extremamente pessoal. [...] Acreditamos que Marília de Dirceu foi até hoje a mais importante coreografia desse idealista, sensibilíssimo e grande artista que é Klauss Vianna. Tudo em Marília de Dirceu é sugestáo, símbolo (a procissão em Ouro Preto vem representada pela passagem de uma santa).

Considero a simplificação, o condensamento e a concisão como difíceis tarefas para os que buscam uma forma clara de expressáo, o que, a meu ver, é a busca de Degois para a capa que descrevo agora. Observo a imagem por ele criada nessa última produção de Vianna para o BKV: um feixe de traços riscados contendo em sua área média, no sentido longitudinal, como núcleo, uma mancha vermelha, único ponto de cor, me faz pensar que entre o branco da página - presença de todas as cores -, dispóem-se os feixes de traços em preto - a ausência de todas as cores -, no qual o ponto vermelho guarda o impulso vital nessa posição média entre dois extremos, decisóes precisam ser tomadas. E Vianna nos aponta, em sua fala, os caminhos possíveis a seguir em suas buscas, táo sutilmente captados por um atento Degois. Do mesmo modo, estendendo sua apreensão à cenografia - com o que nos permitem as imagens utilizadas -, na qual Degois busca sintetizar o ambiente ouro-pretano e barroco dos amantes, misto de oratório (figura 10) sugerido pelas duas custódias (que também lembram elementos florais), como fundo para a intérprete, Angel Vianna, dentro de um aglomerado superposto de verdadeiros barracos no morro (figura 11), próprios da topografia local onde os amantes vivem seu amor inconcluso. Somam-se os comentários das entrevistas que, como documentos da experiência, solidificam aquilo que o discurso teórico de Vianna busca anunciar.

Aqui, em Marília de Dirceu, todo o aprendizado dos tempos iniciais do BKV organiza-se nessa depuração, filtrado e reconduzido em uma linguagem criativa, que passa a expressar um estilo cada vez mais próprio de sua 
subjetividade. Desse modo, penso que o modernismo mineiro de Vianna, com a sua proposta de um balé moderno brasileiro, mostra, finalmente, que náo se trata de um modernismo radical e destruidor do passado, pois que, apesar de romper com normas do balé clássico, no qual o artista se formou, ele continua a fundamentar-se nele para os seus voos mais altos. Segundo sua fala, buscou bases mais simplificadas, porém imprime, em cada obra, o seu pensamento transformador e perspicaz de estudioso, sem os radicalismos comumente assumidos por nomes ligados aos movimentos de caráter modernista. Vianna vai ao encontro do aprimoramento técnico como suporte básico da expressão plena do corpo que dança, treinado pelo balé, mas, inspirado nas tendências da dança moderna.

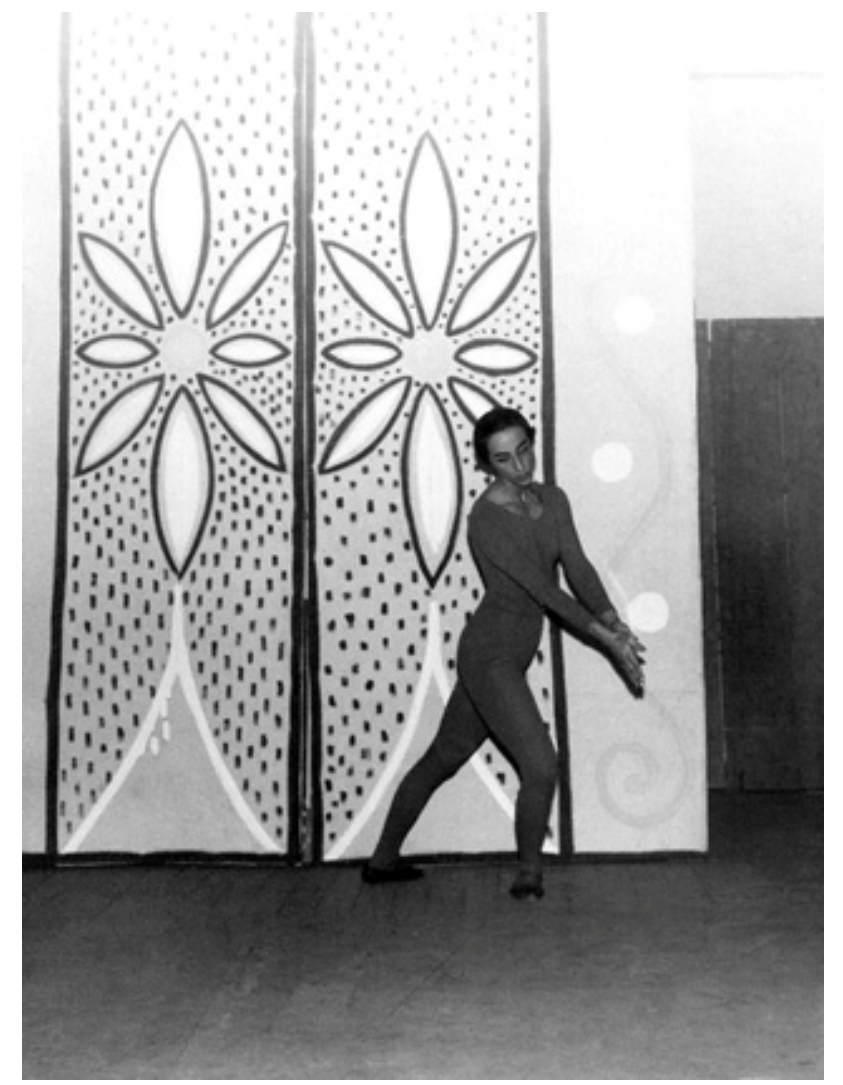

Figura 10 - Coreografia Marília de Dirceu (1962), intérprete Angel Vianna.

Foto: Iannini. Fonte - Acervo do autor. 


\section{Revista Brasileira de Estudos da Presenca Brazilian Journal on Presence Studies}

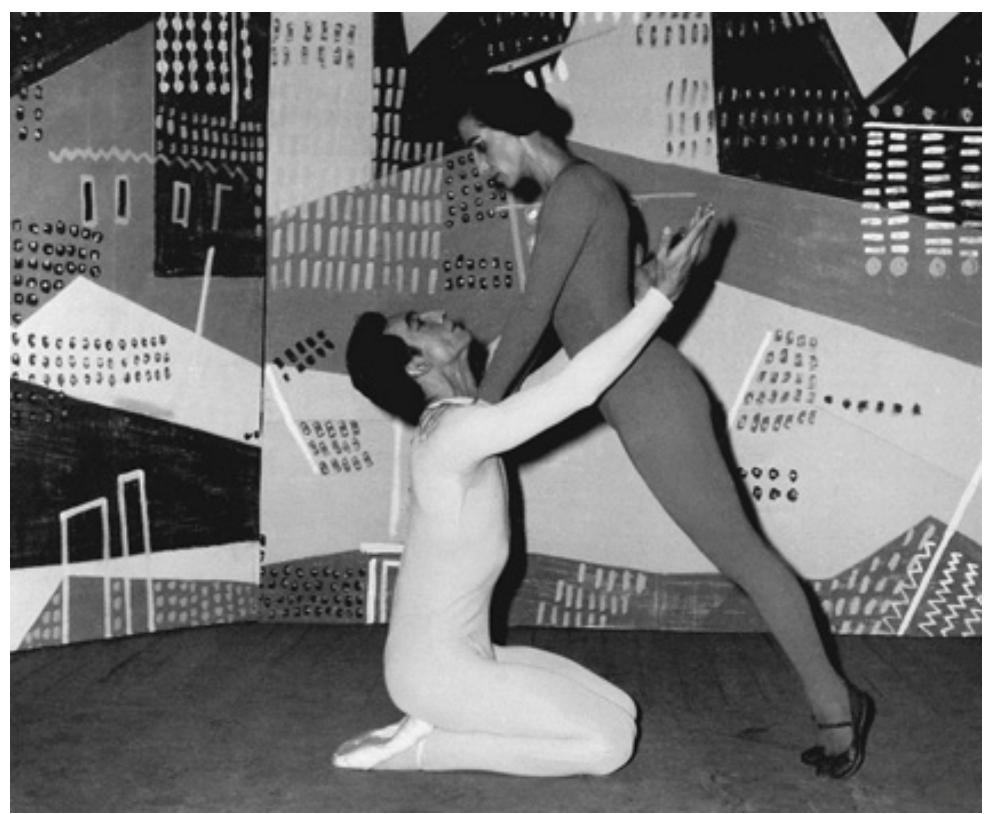

Figura 11 - Coreografia Marília de Dirceu (1962), intérpretes Ceme Jambay e Angel Vianna. Foto: Iannini. Fonte - Acervo do autor.

\section{Expandindo Horizontes}

Os exemplos visuais utilizados ao longo desse texto, tomados às capas dos programas de 4 espetáculos do BKV, bem como as fotografias, substanciadas pelas entrevistas, matérias de jornais e críticas pretenderam contribuir para uma possível historiografia de um determinado período e local do nosso país - Belo Horizonte entre os anos de 1958 à 1962 -, voltado para a compreensão das pesquisas de Klauss Ribeiro Vianna, na construção de uma estética pessoal para um balé moderno brasileiro. Formado sob a influência da cultura europeia, então reinante no balé, Vianna seguirá, posteriormente, um percurso que o aproximará gradativamente de preocupaçóes com o passado nacional por intermédio dos ricos mananciais da cultura regional, tomando como base fatos colhidos junto a uma geração de artistas que se firmava através de mútuas influências de áreas distintas, mas que se irmanavam no ideal de uma criação prenhe de elementos locais, favorecedores de uma expressividade individual. É toda a Geração Complemento, como citado acima, um movimento renovador de intelectuais, pintores, escultores, arquitetos, tapeceiros, cineastas, cantores, músicos e escritores que impulsionou as artes 
mineiras no final dos anos 50 e início dos 60. Nesse envolvimento, as produçôes dos espetáculos de dança do Ballet Klauss Vianna (BKV) deram curso a importantes formas de criação, realçando uma modernidade que, naquele momento, ganhava espaço nos espetáculos de dança em Belo Horizonte e apontava caminhos novos para essa forma de expressão artística, mas com olhos postos no campo maior da dança brasileira.

No conjunto de imagens utilizadas, penso que se pode traçar um percurso de transformação conceitual revelada pela contribuição das Artes Visuais na pessoa de Augusto Degois. Vianna, certamente se viu representado nessas imagens, até porque as aprovou, ampliando espaços já contidos na sua sensibilidade criadora que, agora, atualizamos por uma possível historiografia, reconstrução de um passado que grafado em imagens, mantém viva. As entrevistas, matérias de jornal e críticas fortalecem o que as imagens nos propóem, até porque não estou isento de possibilidades especulativas nas interpretaçóes propostas, assim como o texto das entrevistas podem guardar parcialidades. A história ocorrida não a teremos nunca, todo este artigo sempre será uma construção, como todo o passado revivido. Sem descurarmos das consideraçóes feitas, penso que o texto traz informaçóes relevantes sobre um tema ainda pouco explorado e cheio de possibilidades para muitos pesquisadores, tanto pelo conteúdo tratado como pelo aprimoramento metodológico, aqui proposto por um processo descritivo-interpretativo e apoio textual, visto as peculiaridades dessa arte do movimento, a dança.

O modernismo mineiro de Klauss Vianna, com a sua proposta para um balé brasileiro, mostra, finalmente, como nos aponta Semeghini (2021, p. 22) que

É possível dar-se os meios [...] sendo o artista que tece essa rede de ressonâncias e reconhecimentos. Artista que, antes de ser criador, existe como conector, ou ser de proximidade. [...] Caminhar, parar, deparar-se com o outro ao qual se deseja dirigir novos lampejos.

Ao buscar novos modos de compreender, praticar, transmitir e criar a partir do balé clássico, sua formação, que descreve no livro $A$ Dança (1990), ele imprime, em cada obra, aqui estudadas, o seu pensamento transformador e perspicaz de estudioso em diálogo com as imagens do seu tempo. 


\section{Notas}

1 Nova História - Girando em torno da publicação acadêmica francesa Annales d'histoire économique et sociale, posteriormente conhecida como escola dos Annales, foi um movimento localizado entre historiadores que buscavam novos objetos e métodos de pesquisa, aproximando-se dos procedimentos e ideias das Ciências Sociais, diferenciando-se dos paradigmas tradicionais que ditavam os rumos da pesquisa histórica, até então. Existem vários nomes importantes ligados a diferentes momentos de transformaçáo pelos quais passou o movimento, como: Marc Bloch, Lucien Febvre, Fernand Braudel, Jacques Le Goff, Pièrre Nora, entre outros.

2 Cf. Homans, Jennifer (2012).

3 Cf. Homans, Jennifer (2012, p. 167 e p. 281).

4 Cf. Homans, Jennifer (2012, p. 329).

5 Ver: Cavrel (2015, p. 85-1700).

6 Ver: Silva, (2005, p. 105-143).

7 Cf. Mendes, Ana Carolina (2010, p. 55-80).

8 Ver: Vianna, 1990.

9 Ver: Denis, 1956.

10 Ver: Vieira, 1997, p. 134.

11 Escola Guignard - https://pt.wikipedia.org/wiki/Escola_Guignard Acessado em 27/04/2021.

12 Edith Behring (1916-1996) https://pt.wikipedia.org/wiki/Edith_Behring Acessado em 26/04/2021.

13 Alberto da Veiga Guignard (1896-1962) https://pt.wikipedia.org/wiki/Alberto_da_Veiga_Guignard Acessado em 26/04/2021.

14 João Ceschiatti (1916-1987) http://fcs.mg.gov.br/espacos-culturais/palaciodas-artes/teatro-joao-ceschiatti/. Acessado em 26/04/2021.

15 Entrevista de Angel Vianna em 5/05/2001. Ver: Vianna, 2001. 
16 Semana de Arte Moderna de 1922 - https://pt.wikipedia.org/wiki/Semana_de_Arte_Moderna Acessado em 29/04/21.

17 Proporção Áurea - https://www.google.com/search?q=se $\%$ C3\%A7\%C3\%A3o+\%C3\%A1 urea\&oq=se $\%$ C3\%A7\%C3\%A3o+ \%C3\%A1 urea\&aqs=chrome..69i57j0j0i22i3015.6059j0j4\&sourceid=chrome\&ie=UTF-8. Acessado em 26/04/2021.

18 Faziam parte do programa de estreia as coreografias: Parque de Diversóes; Desfile de Modas, Egmont e Cobra Grande.

19 Entrevista de Angel Vianna em 5/05/2001. Ver: Vianna, 2001.

20 Entrevista de Klauss Vianna à jornalista Amélia Carmem Machado 16/01/1955. Ver: Vianna, 1955.

${ }^{21}$ Entrevista a Antônio César, jornal Última Hora, Belo Horizonte, 1960. Ver: Vianna, 1960c.

22 Ver: Vianna, 1952.

23 A noção de movimento-ideia foi citada, pela primeira vez, no seu ensaio de 1952, Pela criação de um Ballet Brasileiro, lançando a base da renovação pretendida: "O que eu quero conseguir é o que chamo de movimento-ideia, isto é, um ballet cuja construçáo e realização se faça a partir de uma concepçáo fundamental e criadora. Não basta a técnica ou o virtuosismo como solução. É preciso preencher este movimento de uma ideia criadora”.

${ }^{24}$ Entrevista de Klauss Vianna ao jornalista Frederico de Morais. Ver: Vianna, 1958.

25 Amélia Carmem Machado, jornal Diário de Minas: Belo Horizonte, 16/01/55. Ver: Vianna, 1955.

26 Ver: Vianna, 1952.

27 Jornal da Cidade 29/08/1960 10 Caderno. Ver: Crítica, 1960a.

28 Jornal da Cidade 29/08/1960 10 Caderno. Ver: Crítica, 1960a. 
${ }^{29}$ Entrevista de Klauss Vianna ao Jornal da Cidade, Belo Horizonte: 29/08/1960. Ver: Crítica, 1960a.

${ }^{30}$ Entrevista de Klauss Vianna ao Jornal da Cidade, Belo Horizonte: 29/08/1960. Ver: Crítica, 1960a

${ }^{31}$ Entrevista de Klauss Vianna ao Jornal Diário de Minas. Ver: Vianna, 1960a.

${ }^{32}$ Entrevista Angel Vianna - Rio de Janeiro, 5/05/2001. Ver: Vianna, 2001.

${ }^{33}$ Entrevista Angel Vianna - Rio de Janeiro, 5/05/2001. Ver: Vianna, 2001.

${ }^{34}$ No programa de 1959, constavam as seguintes coreografias: Suite Clássica; Estudo; o pas des deux de Dom Quixote; Neblina de Ouro e o Caso do Vestido.

${ }^{35}$ No programa de 1959, constavam as seguintes coreografias: Suite Clássica; Estudo; o pas des deux de Dom Quixote; Neblina de Ouro e o Caso do Vestido.

${ }^{36}$ Matéria do Jornal da Cidade - Belo Horizonte, 29/08/1960. Ver: Crítica, 1960a.

${ }^{37}$ Matéria de periódico não identificado, de setembro de 1960.

${ }^{38}$ Entrevista de Angel Vianna - Rio de Janeiro, 5/05/2001. Ver: Vianna, 2001.

${ }^{39}$ Machado, Lúcia Helena. A Filha da Paciência, p. 26. Ver: Machado, 2000.

${ }^{40}$ Crítica do jornal O Estado de São Paulo, 9/11/1960. Ver: Crítica, 1960b.

${ }^{41}$ Entrevista Angel Vianna - Rio de Janeiro, 5/05/200. Ver: Vianna, 2001.

${ }^{42}$ Entrevista Angel Vianna - Rio de Janeiro, 5/05/2001. Ver: Vianna, 2001.

${ }^{43}$ Entrevista concedida à jornalista Haydée, do Diário de Minas, em 11/09/1960. Ver: Vieira, 1960.

${ }^{44}$ Jornal Estado de Minas, de setembro de 1960. Ver: Marschner, 1960.

${ }^{45}$ No programa, constavam as seguintes coreografias: Concerto Barroco; Delírio (coreografia de Denis Grey); Dança da Fita; Jazz; Caso do vestido; Solidão (remontagem da coreografia Neblina de Ouro) e Arabela, a donzela e o mito.

${ }^{46} \mathrm{O}$ Movimento Concretista na poesia surge após a segunda guerra mundial, compreendendo uma série de inovaçóes e experiências, eliminando o verso como unidade rítmico-formal, em uma tentativa de alargar possibilidades de expressão 
e comunicação do poema. São considerados os fundadores da poesia concreta o suíço-boliviano Eugen Gomringer (1955) e, quase simultaneamente, no Brasil, o grupo da revista Noigrandes - Décio Pignatari e os irmáos Augusto e Haroldo de Campos. A experiência concretista no Brasil alterou profundamente o contexto da poesia nacional, sendo o primeiro movimento literário brasileiro a aparecer na vanguarda do movimento mundial. Ver: Enciclopédia, 1980.

${ }^{47} \mathrm{O}$ Abstracionismo Geométrico foi uma das duas grandes correntes da arte abstrata, ou seja, a abstração cezanniana e a abstração lírica, estando ligado a primeira. O pintor Mondrian foi seu grande representante, buscando construir, com bases geométricas, objetos artísticos cuja validade provém de sua própria estrutura. Através das linhas verticais e horizontais, Mondrian buscava pela sua intersecção o ângulo reto - e por extensão o quadrado - ao que se somavam as três cores primárias (vermelho, azul e amarelo), além das não-cores (branca, preta) e o cinza. A atividade do pintor era concebida como uma ordenação desses elementos, excluindo-se toda semelhança com a natureza, mas também todo sentimento, paixáo e individualidade. No Brasil, o movimento Construtivista denominou-se Concretismo, Neoconcretismo e mesmo Abstracionismo Geométrico, sendo um dos mais férteis e regulares da arte nacional. Teve como representantes Franz Weissmann, Amílcar de Castro, Antônio Lizárraga, Sérgio de Carvalho, Mira Schendel e a grande Lygia Clark; o seu período áureo foram as décadas de 50 e 60. Ver: História, 1995.

48 Entrevista de Klauss Vianna ao Jornal da Cidade, em Belo Horizonte, 29/08/1960. Ver: Vianna, 1960b.

${ }^{49}$ Entrevista em periódico não identificado, de setembro de 1960.

${ }^{50}$ Jornal da Cidade - Belo Horizonte, 29/08/1960. Ver: Crítica, 1960a.

${ }^{51}$ Jornal O Estado de São Paulo - São Paulo, 9/11/1960. Ver: Crítica, 1960b.

52 Entrevista de Angel Vianna - Rio de Janeiro, 5/05/2001. Ver: Vianna, 2001.

${ }^{53}$ Entrevista de Angel Vianna - Rio de Janeiro, 5/05/2001. Ver: Vianna, 2001.

${ }^{54}$ Cf. Alvarenga, Arnaldo Leite de (2002) Dissertação de Mestrado. 
${ }^{55}$ No programa constavam as seguintes coreografias: Suite Clássica; O Circo (primeira coreografia de Angel); Suite de Danças Antigas e Marilia de Dirceu.

56 Entrevista concedida ao jornalista Frederico de Morais, 24/11/1962. Ver: Vianna, 1958.

57 Entrevista concedida ao jornalista Frederico de Morais, 24/11/1962. Ver: Vianna, 1958.

${ }^{58}$ Cf. Alvarenga, Arnaldo Leite de (2009). Tese de Doutorado.

${ }^{59}$ Ricardo Teixeira de Sales - Entrevista. Ver: Sales, 2007.

${ }^{60}$ Lia Robatto - entrevista a Ricardo Baretto. Ver: Robatto, 2007.

${ }^{61}$ Eduardo Virlmont - Diário do Paraná. Curitiba, 14 de setembro de 1962. Ver: Virlmont, 1962.

${ }^{62}$ Eduardo Virlmont - Diário do Paraná. Curitiba, 14 de setembro de 1962. Ver: Virlmont, 1962

${ }^{63}$ Lúcia Machado de Almeida - Jornal de Minas. Belo Horizonte 11/1962.

${ }^{64}$ Lúcia Machado de Almeida - Jornal de Minas (Belo Horizonte) 11/1962.

\section{Referências}

ALMEIDA, Lúcia Machado de. Crítica, Jornal de Minas, Belo Horizonte, novembro de 1962.

ALVARENGA, Arnaldo Leite de. Dança Moderna e Educaçáo da Sensibilidade: Belo Horizonte (1959 - 1975). Programa de Pós-Graduação em Educação e Inclusão Social/FAE - UFMG, 2002. Dissertação de Mestrado.

ALVARENGA, Arnaldo Leite de. Klauss Vianna e o Ensino de Dança: uma Experiência Educativa em Movimento (1948 - 1990), Programa de Pós-Graduação em Educação e Inclusão Social/FAE UFMG, 2009. Tese de Doutorado.

ANJOS, Cyro dos. O Amanuense Belmiro. Rio de Janeiro: José Olympio Editora, 1937. 
ÁVILA, Cristina. Guignard, as geraçôes pós-Guignard e a consolidação da Modernidade. In: RIBEIRO, Marília Andrés; SILVA, Fernando Pedro da (org.). Um Século de História das Artes Plásticas em Belo Horizonte. Belo Horizonte: C/Arte, Fundação João Pinheiro e Centro de Estudos Históricos e Culturais, 1997. BARBOSA, Andréa; CUNHA, Edgar Teodoro. Antropologia e imagem. Rio de Janeiro: Jorge Zahar, 2006.

CAVREL, Holly Elizabeth. Dando Corpo à História. Curitiba: Editora Prismas, 2015.

CRÍTICA. Jornal da Cidade, Belo Horizonte, 29 de agosto de 1960a.

CRÍTICA. O Estado de Sáo Paulo, São Paulo, 9 de novembro de 1960b.

DENIS, Carlos. A Revista da Nova Geração. Estado de Minas, 24 de julho de 1956.

ENCICLOPÉDIA Mirador Internacional. São Paulo: Melhoramentos, 1980. Volume 16.

GULLAR, Ferreira. Argumentaçáo contra a morte da arte. Rio de Janeiro: Revan, 1997.

HISTÓRIA Geral da Arte: O Objeto Artístico. Rio de Janeiro: Ediçóes del Prado, 1995.

HOMANS, Jennifer. Os Anjos de Apolo: uma história do balé. Ediçóes 70: Lisboa, 2012.

KNAUSS, Paulo. Aproximaçóes disciplinares: história, arte e imagem. In: Anos 90, Porto Alegre, v. 15, n. 28, p. 151-168, dez. 2008.

LE GOFF, Jacques. História e Memória. Campinas: Editora da UNICAMP, 2003.

MACHADO, Amélia Carmem. [s.n.]. Diário de Minas, Belo Horizonte, 16 de janeiro de 1955.

MACHADO, Lúcia Helena. A Filha da Paciência. Belo horizonte: BDMG Cultural, 2001.

MARSCHNER, João. Crítica. Estado de Minas, setembro de 1960.

Arnaldo Leite de Alvarenga - O Ballet Klauss Vianna em Belo Horizonte (1958-1962): caminhos de uma 
MENDES, Ana Carolina. Dança Contemporânea e o Movimento tecnologicamente Contaminado. Brasília: Editora IFB, 2010.

NOTICIÁRIO Artístico. Belo Horizonte, [s. d.].

ROBATTO, Lia. [Entrevista concedida a] Ricardo Baretto. Projeto Klauss Vianna, Um Resgate Histórico. Salvador, 29 de agosto de 2007.

PESAVENTO, Sandra Jatahy. História e história cultural. Belo Horizonte: Autêntica, 2003.

SALES, Ricardo Teixeira de. Entrevista a Arnaldo Alvarenga, Belo Horizonte, 22 de maio de 2007.

SILVA, Eliana Rodrigues. Dança e pós-modernidade. Salvador: EDUFBA, 2005.

SEMEGHINI, Juliana Raposo. Dançar o Patrimônio Urbano. Revista Brasileira de Estudos da Presença, v. 11, n. 1, Porto Alegre, 2021. Disponível em: <https:/www.scielo.br/pdf/rbep/v11n1/pt_2237-2660-rbep-11-01-e94914.pdf z. Acesso em 28/04/21.

VELASCO, Bárbara Marcela Reis Marques de. Nazismo por imagens. Em Tempo de Histórias - Publicação do Programa de Pós-Graduação em História PPG-HIS/UnB, n.10, Brasília, 2006.

VIANNA, Angel. [Entrevista a Arnaldo Alvarenga]. Rio de Janeiro, 5 de maio de 2001.

VIANNA, K. Pela Criaçáo de um Ballet Brasileiro. Revista Horizonte, Belo horizonte, 1952.

VIANNA, Klauss. Pela primeira vez em belo horizonte um espetáculo de ballet com coreografia moderna. [Entrevista concedida a] Amélia Carmem Machado. Diário de Minas, Belo Horizonte, 16 de janeiro de 1955. Disponível em: $<$ http://www.klaussvianna.art.br/busca_detalhes.asp?busca $=\& \mathrm{x}=13 \& \mathrm{y} \#[$ showDet]242>. Acesso em set. 2021.

VIANNA, Klauss. É preciso que o ballet tenha consciência nacional. [Entrevista concedida a] Frederico de Morais. O Diário, Belo Horizonte, 13 de abril de 1958. Disponível em: < http://www.klaussvianna.art.br/busca_detalhes.asp? busca $=\& \mathrm{x}=13 \& \mathrm{y} \#[$ showDet $] 247>$. Acesso em set. 2021. 
VIANNA, Klauss. Minha intenção é refletir a índole do povo e não suas exterioridades. [Entrevista concedida a] Marilena e Jura. Diário de Minas, Belo Horizonte, 28 de agosto de 1960a. Disponível em: < http://www.klaussvianna.art.br/busca_detalhes.asp?busca $=\& x=13 \& y \#[$ showDet $] 713>$. Acesso em set. 2021.

VIANNA, Klauss. [Entrevista concedida ao] Jornal da Cidade, Belo Horizonte, 29 de agosto de $1960 \mathrm{~b}$.

VIANNA, Klauss. [Entrevista concedida a] Antônio César. Última Hora, Belo Horizonte, 1960c.

VIANNA, Klauss. A Dança. São Paulo: Siciliano, 1990.

VIEIRA, Ivone Luzia. Emergência do Modernismo. In: RIBEIRO, Marília Andrés; SILVA, Fernando Pedro da (org.). Um Século de História das Artes Plásticas em Belo Horizonte. Belo Horizonte: Ed. C/ Arte: Fundação João Pinheiro, 1997. VIEIRA, José Aurélio. [Entrevista concedida a] Haydée. Diário de Minas, Belo Horizonte, 11 de setembro de 1960.

VIRLMONT, Eduardo. Crítica. Diário do Paraná, Curitiba, 14 de setembro de 1962.

Arnaldo Leite de Alvarenga formou-se no Trans-Forma Centro de Dança Contemporânea e em Leitura Corporal (Fisiognomonia) pelo Núcleo de Terapia Corporal (BH - MG). Prêmios de bailarino, coreógrafo e roteirista do Minc-Inacem (1986) e Klauss Vianna - Dança 2006 e 2009 da FUNARTE. Graduado em Geologia UFMG; Mestre e Doutor em Educação FAE - UFMG. Docente das Graduaçóes de Teatro e de Dança, e, da Pós-Graduação em Artes - PPGArtes da EBA-UFMG. Presidente da ABRACE - Associação Brasileira de Pesquisa e Pós-Graduação em Artes Cênicas (2013-2014). Tem livros e artigos na área de Memória e História da Dança no Brasil.

ORCID: https://orcid.org/0000-0003-3427-0829

E-mail: alda1702a@gmail.com

Este texto inédito também se encontra publicado em inglês neste número do periódico. 
Recebido em 29 de abril de 2021 Aprovado em 23 de agosto de 2021 Editores responsáveis: Cassia Navas Henrique Rochelle Gilberto Icle Arnaldo de Siqueira Junior

Este é um artigo de acesso aberto distribuído sob os termos de uma Licença Creative Commons Atribuiçáo 4.0 Internacional. Disponível em: <http://creativecom mons.org/licenses/by/4.0>. 